\title{
Quaternary Tectonic Deformation, Holocene Paleoseismicity, and Modern Strain in the Unusually-Wide Coupled Zone of the Central Cascadia Margin, Washington and Oregon, USA, and British Columbia, Canada
}

\author{
Curt D. Peterson ${ }^{1} \&$ Kenneth M. Cruikshank ${ }^{1}$ \\ ${ }^{1}$ Portland State University, Portland, Oregon, USA \\ Correspondence: Curt D. Peterson, Geology Department, Portland State University, Portland, OR, 97207-0751, \\ USA. Tel: 1-503-730-9266. E-mail: curt.d.peterson@gmail.com
}

Received: February 22, 2014 Accepted: May 15, 2014 Online Published: June 20, 2014

doi:10.5539/jgg.v6n3p1 URL: http://dx.doi.org/10.5539/jgg.v6n3p1

\begin{abstract}
Vertical deformation and horizontal strains are analyzed in the central Cascadia margin, or the Juan de Fuca plate segment of the Cascadia subduction, zone to establish the widths of the inter-plate strongly-coupled zone and the transition zone. Local variability of marine terrace elevations, corresponding to marine isotope stages $5 \mathrm{a}-5 \mathrm{e}(\sim 80-130 \mathrm{ka})$, in the south and central Oregon coast $(32 \pm 23 \mathrm{~m}-$ to- $-10.5 \pm 7.4 \mathrm{~m}$ mean sea level) and in the northern Oregon and Washington coasts $(9.5 \pm 3.2 \mathrm{~m}$-to- $-7.6 \pm 2.1 \mathrm{~m})$, constrain the width of the strongly coupled zone $(\sim 100 \mathrm{~km})$ from the deformation front or buried trench along the central Cascadia margin in Washington and Oregon. Late Holocene tidal marsh sites (number $=25$ ) in Washington demonstrate three conditions of cyclic coseismic subsidence, representing the first and second zero-isobases $(<0.5 \mathrm{~m}$ sea level rise) and the trough of maximum coseismic subsidence $(1.0 \pm 0.5 \mathrm{~m}$ or $>1.5 \mathrm{~m}$ abrupt sea level rise) for most rupture events during the last $2.6 \mathrm{ka}$. Together with paleosubsidence data from the Oregon coast the tidal wetland records in Washington show that the first and second zero-isobases, respectively, reach distances of $\sim 100$ and $\sim 200 \mathrm{~km}$ from the deformation front in the central Cascadia subduction zone. Global positioning system (GPS) baselines show that across-margin crustal shortening (strain rate $-5 \times 10^{-8}$ to $-1.5 \times 10^{-6} \mathrm{a}^{-1}$ ) is about one order of magnitude larger than along-margin shortening (strain rate $-2 \times 10^{-8}$ to $-5 \times 10^{-7} \mathrm{a}^{-1}$ ) near the coast during the last several years. Significant negative strain or shortening in the upper-plate is measured to $200 \mathrm{~km}$ distance from the deformation front, thereby establishing an unusually wide coupled zone $(\sim 200 \mathrm{~km})$ in the central Cascadia margin. The landward limits of the west coupled zone, central uncoupled zone, and east coupled zone, respectively, could account for long-term uplift of the Coast Ranges, the lack of uplift in the Puget and Willamette forearc valleys, and uplift of the western margin of the Cascade volcanic arc.
\end{abstract}

Keywords: inter-plate coupled zone, marine terrace uplift, coseismic subsidence, GPS strain

\section{Introduction}

In this paper the geometries of upper-plate inelastic and elastic deformation in the central Cascadia subduction zone (Figure 1) are interpreted from geologic records of vertical displacements and horizontal strain. These deformation and strain records are used to establish 1) the across-margin extent of the upper-plate fold and fault belt or the deformation belt, 2) the width of the trough of coseismic subsidence between the first and second zero-isobases, and 3) the across-margin extent of the inter-plate coupled zone in the central Cascadia margin. We use the term central Cascadia margin to represent the subduction zone area that is located landward of the young $(<20 \mathrm{Ma})$ and thermally-buoyant Juan de Fuca plate segment, which is descending at shallow angles $\left(5-12^{\circ}\right)$ under the North American Plate (e.g., Parsons et al., 2005).

The Cascadia margin is of historic importance, as it was the first subduction zone to undergo a significant seismic zone upgrade, from UBC Zone 2 to Zone 3 in western Oregon in 1993, based entirely on paleoseismic records $(\mathrm{OBCD}, 2012)$. The last great Cascadia earthquake (Mw 8.5 \pm 0.5 ) occurred in $\mathrm{AD} 1700$ (Satake et al., 1996) about $150 \mathrm{yr}$ before continuous European settlement. Recurrence intervals of the prehistoric great earthquakes $(500 \pm 300 \mathrm{yr})$ were initially established from coseismically-subsided marsh horizons (Darienzo \& Peterson, 1990; Darienzo \& Peterson, 1995; Atwater \& Hemphill-Haley, 1997). Minimum lengths of most 
ruptures (300-500 km) are estimated from 1) along-margin correspondence between local marsh subsidence and regional paleotsunami deposits (Peterson \& Darienzo, 1996; Peterson et al., 2010a, 2013a) and 2) along-margin continuity of continental slope turbidite sequences (Adams, 1996; Goldfinger et al., 2008; Blais-Stevens et al., 2011). However, the interpreted west-east width of the inter-plate coupled zone or seismogenic zone has remained controversial. Interpreted coupled zone widths range from $50-75 \mathrm{~km}$, as based on plate-segment bounding faults in the mid-shelf (Goldfinger et al., 1992a) and geothermal modeling (Leonard et al., 2010; Witter et al., 2013) to at least $150 \mathrm{~km}$ width (Peterson et al., 2012a), using modern strain rates in coastal GPS station baselines in Oregon (Figure 1).

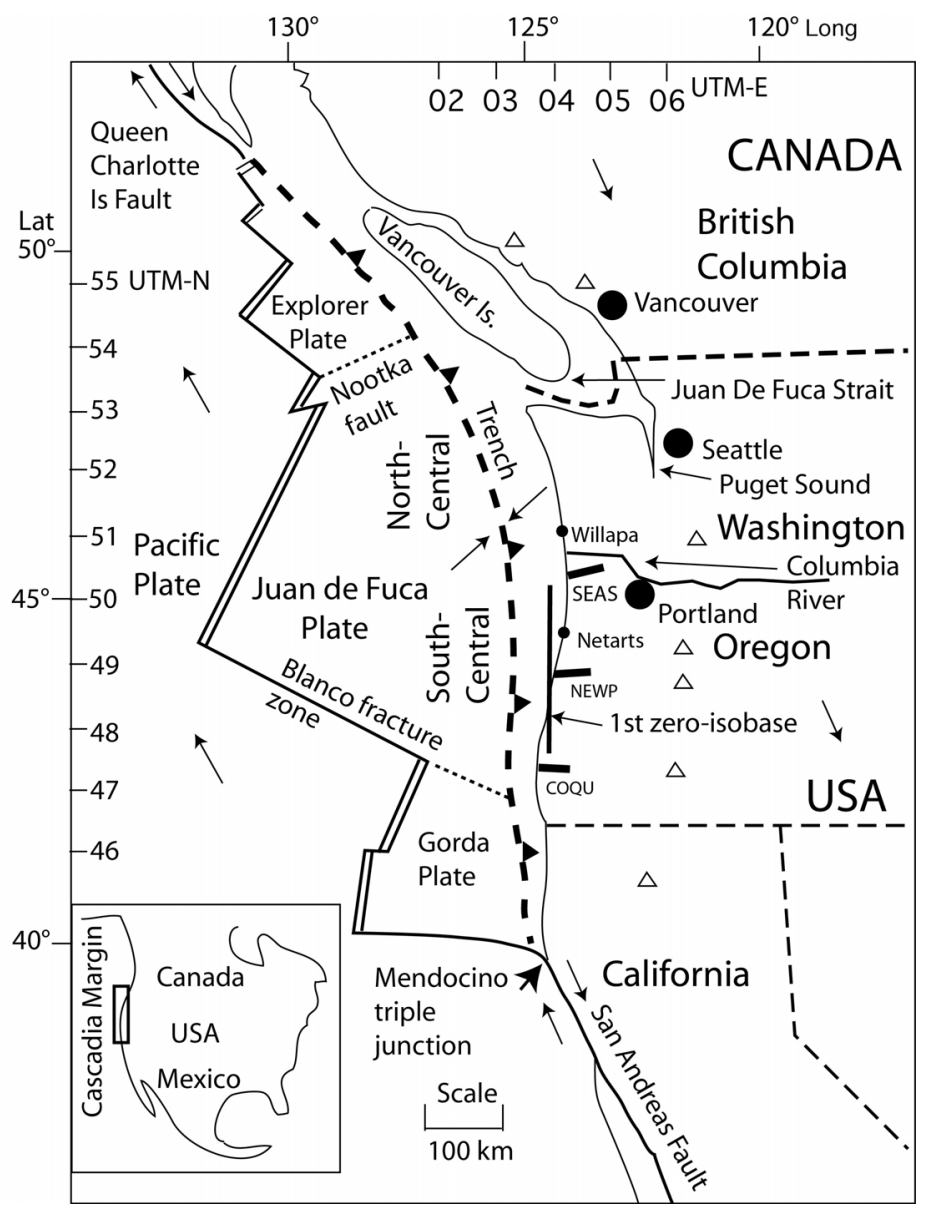

Figure 1. Location map of the Cascadia subduction zone study region

North-central and south-central portions of the subducting Juan de Fuca plate segment are bounded (dotted lines) to the north by the Explorer plate segment and to the south by the Gorda plate segment. Relative plate tectonic motions (short arrows) are shown. Prominent volcanoes (open triangles) outline the Cascade volcanic arc. The two estuaries (small dark circles) that provided the first records of coseismic subsidence in Washington and Oregon, respectively, are Willapa Bay and Netarts Bay. The deformation front or buried trench is shown with a dashed line (down-dipping to the east). The first zero-isobase (vertical bold line) is shown crossing the south-central Oregon coast. Three inland tidewater bodies (arrows) include the Strait of Juan de Fuca, Puget Sound, and Lower Columbia River. Three GPS station transects including SEAS, NEWP and COQU (sub-horizontal black bars) were used to establish modern crustal shortening (west-east) well landward of the coastline in the south central Cascadia margin (Peterson et al., 2012a).

Herein the widths of the inter-plate coupled zones across the central Cascadia margin are established from geologic records of 1) marine terrace relative uplift ( 100,000 yr time scale), 2) the trough of coseismic subsidence events between the first and second zero-isobases (last 2,600 yr) and 3) modern strain measurements from extended global positioning system (GPS) station baselines (since 2005). Based on Saffer and Bekins (2006) the across-margin extent of the upper-plate fold and fault belt should approximate the width of the 
strongly coupled portion of the inter-plate megathrust in the subduction zone (Figure 2). The positions of the trough of coseismic subsidence and the first zero-isobase are important parameters because they are used in modeling tsunami excitation (Geist, 2005). The recognition of an unusually-wide coupled zone in the central Cascadia margin, as first reported here, should have direct relevance to estimating the potential strength of coseismic shaking from future great earthquakes in the large metropolitan areas of Portland, Oregon, Seattle, Washington, and Vancouver, British Columbia (Figure 1).

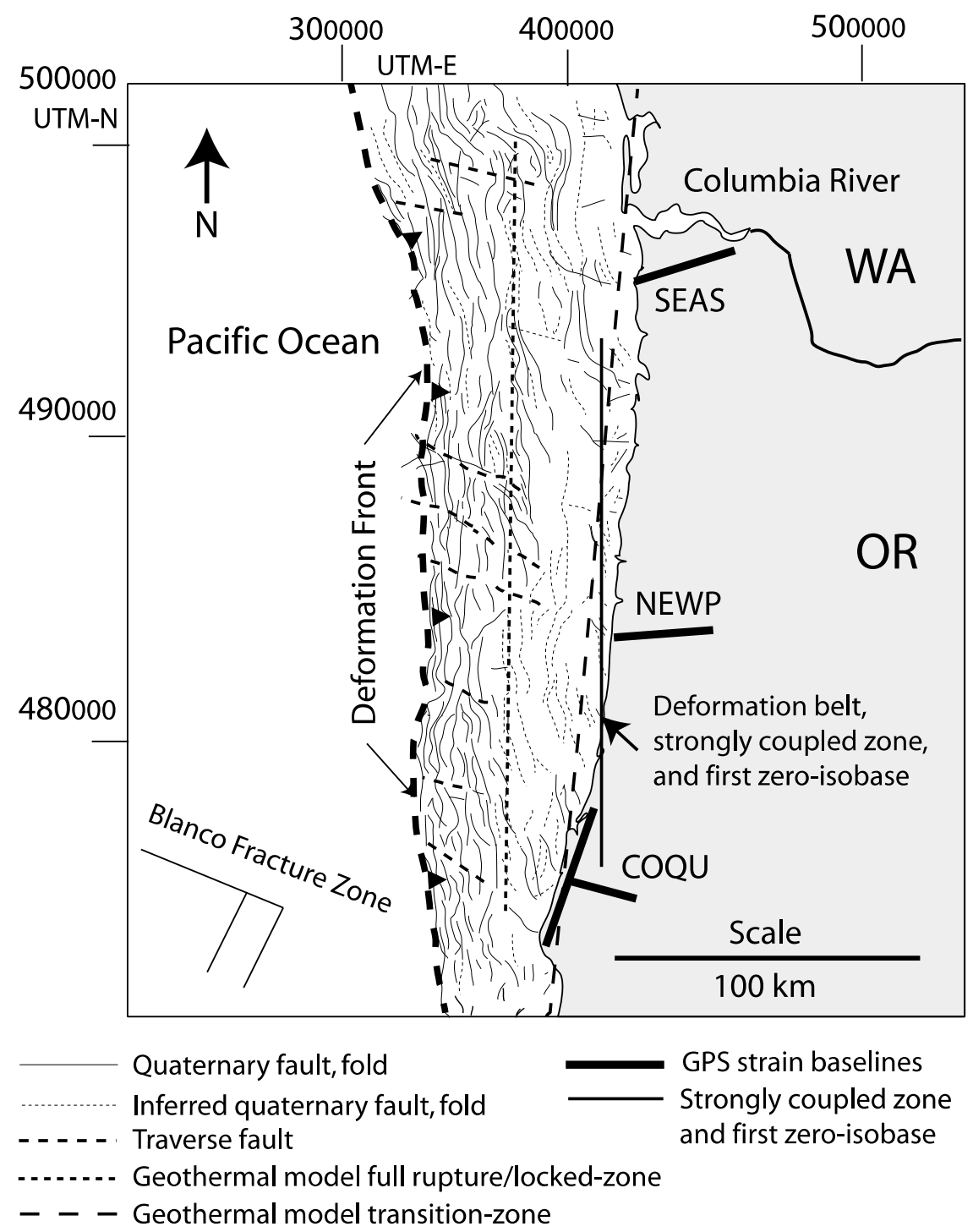

Figure 2. Map of offshore Quaternary-age deformation features

Folds and faults (lines) and inferred Quaternary folds and faults (dashed lines) are shown in the offshore deformation belt, as located landward of the deformation front in Oregon and southernmost Washington. Across-margin faults (bold dashed lines) have been proposed as plate segment boundaries (Goldfinger et al., 1992a). Geothermal models suggest a narrow full rupture or locked zone and a narrow transition zone (Witter et al., 2013). The landward extent of the strongly coupled zone (Peterson et al., 2012a), as based on deformation of Tertiary rocks and late Pleistocene marine terraces, indicates a wide strongly coupled zone, that intersects the coastline in south-central Oregon. The position of the first zero-isobase (thin solid line) is also shown to intersect the coastline in south-central Oregon (Peterson et al., 2012a). GPS strain baselines are shown (thick black bars) at SEAS, NEWP and COQU. Modern shortening in the GPS baselines (Peterson et al., 2012a) indicates that inter-plate coupling extends well landward of the coastline and well landward of the geothermal model transition zone (Witter et al., 2013). Offshore Quaternary folds and faults are redrafted from Goldfinger et al. (1992b) as compiled by McNeil et al. (1998). 


\section{Background}

An early study of coastal neotectonics in the south central Cascadia margin (Peterson \& Gray, 1986) investigated the sources of marine terrace deformation (Adams, 1984) by compiling maps of onshore terrace deformation with offshore Quaternary faults and folds. The early mapping of offshore Quaternary structures in the continental shelf (Peterson et al., 1986) was substantially refined in the south central Cascadia margin (Figure 2) and extended to the north central Cascadia margin by Goldfinger et al. (1992b). Transverse faults were found to extend from the deformation front to the mid-shelf. These transverse faults were reported to represent plate segment boundaries that limited inter-plate rupture lengths, thereby prohibiting Mw 8 earthquakes (Goldfinger et al., 1992a; McCaffrey \& Goldfinger, 1995; Goldfinger et al., 1997). The transverse faults were not traced to the inner-shelf or to coastal marine terrace exposures. Coupled zone widths in the south central Cascadia margin have been predicted by thermal modeling of the inter-plate interface (Hyndman \& Wang, 1993, 1995). Thermal modeling results extended the locked-zone to the mid-shelf and the transition zone to the coastline, yielding potential rupture widths of less than $100 \mathrm{~km}$ from the trench.

To test the minimum width of the coupled zone in the south central Cascadia margin the coastal marine terraces (marine isotope stages MIS-5) of 80-130 ka in age were measured for local vertical deformation or height using a statistical evaluation of the terrace elevations measured within along-margin intervals (Peterson et al., 2012a). Thrusts and folds occur in the upper-plate deformation belt, which is located above the strongly coupled zone of the inter-plate megathust (Saffer \& Bekins, 2006). The statistical variability's of the vertically deformed marine terraces were found to increase with increasing shoreline proximity to the deformation front. The greatest change in along-margin height variability occurs in the south-central Oregon coastline (Figure 2), which defines the landward reach of the strongly coupled zone (Peterson et al., 2010a). In the south central Cascadia margin the strongly coupled zone, extends about $100 \mathrm{~km}$ landward of the deformation front.

Uncertainty exists concerning the landward extent of the strongly coupled zone in the north central Cascadia margin (Fisher et al., 2005) and whether the offshore deformation belt (McNeil et al., 1998; McCory et al., 2005) manifests onshore in the vicinity of the central coast of Washington State. Herein we evaluate the variability of marine terrace elevations (Heusser, 1977; Clifton, 1994; Thackray, 1998) in the south and central coasts of Washington to help constrain the width of the upper-plate deformation belt along the north central Cascadia margin.

Along the south central Cascadia margin the landward extent of the inelastic deformation belt, containing abundant margin-parallel faults and folds (Figure 2) is approximately coincident with the coastline crossing of first zero-isobase of interseismic elastic deformation (Figure 1) (Peterson \& Darienzo, 1996; Briggs, 1994; Peterson et al., 2000, 2012a). Episodic coseismic subsidence occurs landward of the first zero-isobase (Figure 3). Geologic records of late Holocene coastal subsidence events (0.5-2.0 m abrupt sea-level rise) in estuarine salt marshes from Willapa Bay (Atwater, 1987) and Netarts Bay (Darienzo \& Peterson, 1990), among many other tidal bays (Atwater et al., 1995), led to the recognition that the central Cascadia margin represents a coseismic subduction zone. The trough of coseismic subsidence occurs landward of the first zero-isobase in the northern Oregon coast, however, no inland tidewater bodies are present south of the Columbia River (Figures 1 and 2) to establish the landward position of the second zero-isobase. 


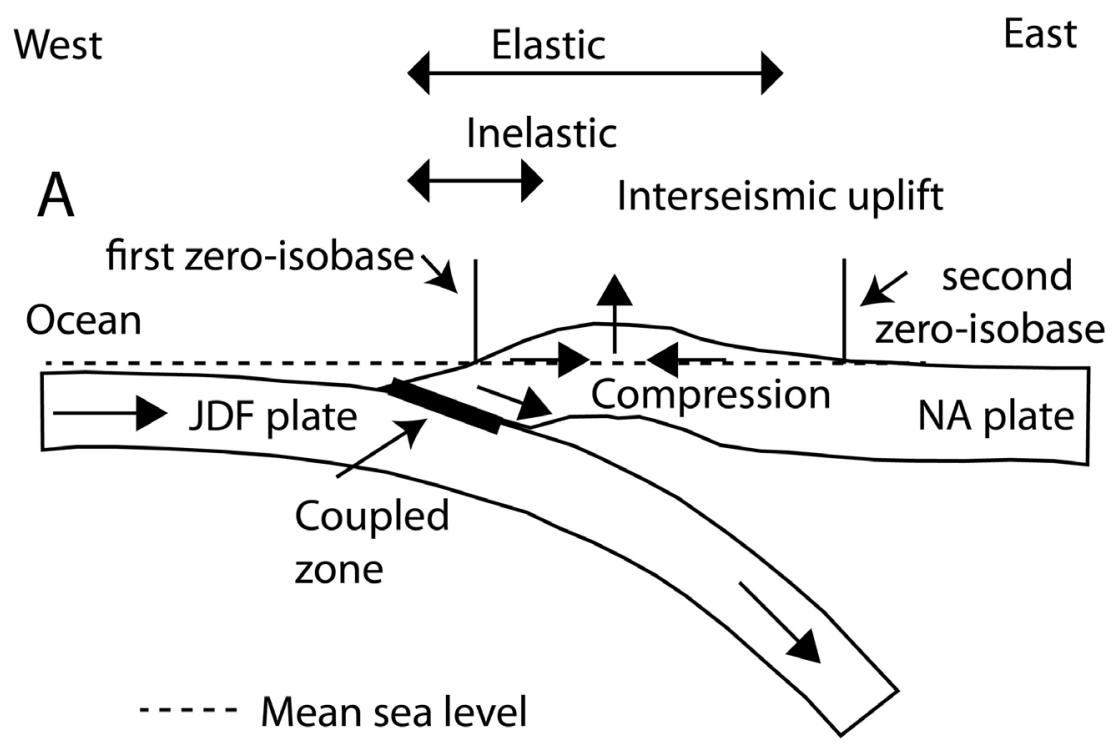

\section{B Coseismic subsidence}

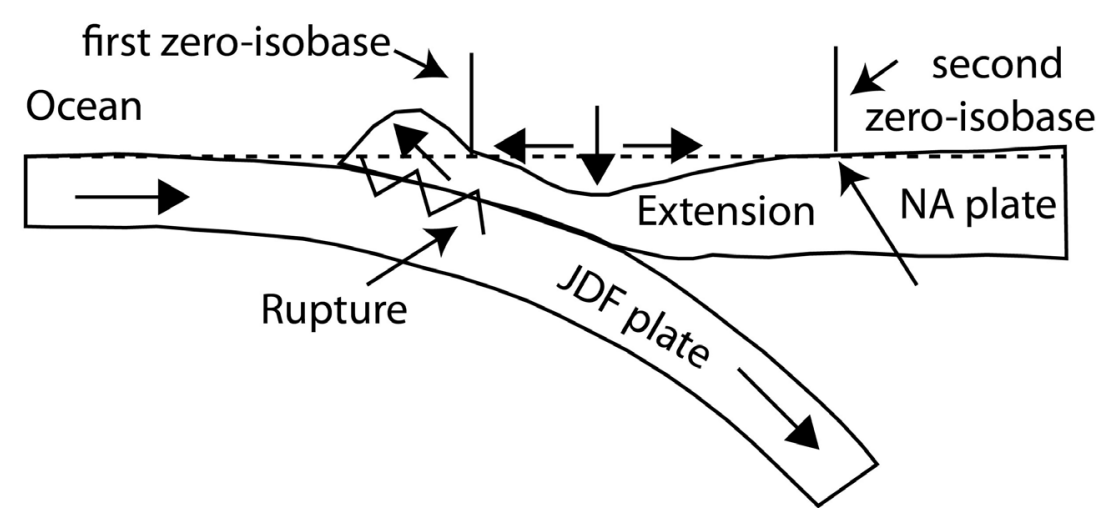

Figure 3. Schematic cross-section through a moderate dipping subduction zone

Plate motions shown during 1) interseismic intervals of plate coupling and elastic strain accumulation (Part A) and 2) coseismic intervals of megathrust rupture and strain release (Part B) in subduction zones. Vertical deformation cycles reverse in direction on opposite sides of the first zero-isobase. Diagram is not to scale.

Tidewater marshes occur both along the Pacific coast of Washington, as well as the Strait of Juan de Fuca and the Puget Sound, both of which occur at least $100 \mathrm{~km}$ inland of the Washington coast (Figure 1). Late Holocene wetland deposits in these tidewater bodies provide records that 1) establish the trough of coseismic subsidence (Atwater, 1997; Peterson et al., 2000) and 2) should approximate the landward limits of coseismic subsidence or the second zero-isobase for the majority of latest Holocene ruptures (Peterson et al., 2012a). In this paper we compile previously published subsidence records and some new wetland geologic records from selected tidal marshes in Washington to establish the landward extent of the trough of coseismic subsidence and the approximate position of the second zero-isobase in the north central Cascadia margin.

Modern GPS records have been used in the south central Cascadia margin to test for current horizontal strain accumulating landward of the Oregon coast in the upper-plate (Figure 2) (Peterson et al., 2012a). Much of that compressive strain is assumed to be elastic (Cruikshank \& Peterson, 2013), with both extensional relaxation and seismic energy release expected to occur during megathrust ruptures. Unlike GPS velocity solutions (McCaffrey et al., 2007) no regional rotation factors are involved in the GPS station-to-station baseline distances that are used to derive the direct strain measurements. Such GPS strain analyses are likely to replace some GPS velocity analyses in seismogenic megathrust zones where potential coseismic energy release might be estimated from extrapolated records of modern elastic strain accumulation (Cruikshank \& Peterson, 2013).

Results from the GPS strain records (2008-2011) in the south central Cascadia margin (Figure 2) show 
horizontal west-east shortening strain to reach at least $50 \mathrm{~km}$ landward of the Oregon coastline (Peterson et al., 2012a). A north-south component of upper-plate shortening was also apparent in the GPS strain data from the southwest Oregon coast. The north-south strain suggests some north-south compression from oblique subduction (Figure 1). Such direct strain measurements have not been reported from the North Central Cascadia Margin. In this paper we examine three west to east GPS strain baseline traverses and one north-south strain baseline traverse for modern strain accumulation in the upper-plate of the central Cascadia margin.

\section{Methods}

Sea cliffs along the central Washington coast (Figure 4) expose late Pleistocene wave-cut platforms that are cut into bedrock and are themselves overlain by beach sediments and/or glacial outwash and loess deposits (Huesser, 1977; Thackray, 1998). These terraces correspond to high-stand conditions during marine isotope stages MIS-5 (85-130 ka) or MIS-7 (200-240 ka) (Specmap, 2013). Marine terraces from the north Washington coast, located north of La Push, Washington, might have been exposed to direct glacial scour and/or glacial isostatic loading from the Cordillera lobe exiting the Strait of Juan de Fuca [Rau, 1979] so they are not used here for evidence of local tectonic deformation. The south Washington coast was protected behind extensive barriers during latest Pleistocene time (Smith et al., 1999), so marine terrace elevations in that area are taken from uplifted tidal flat deposits [Clifton, 1994] and barrier lagoon deposits (Mulder, 1992), that correspond to MIS-5 marine high stands.

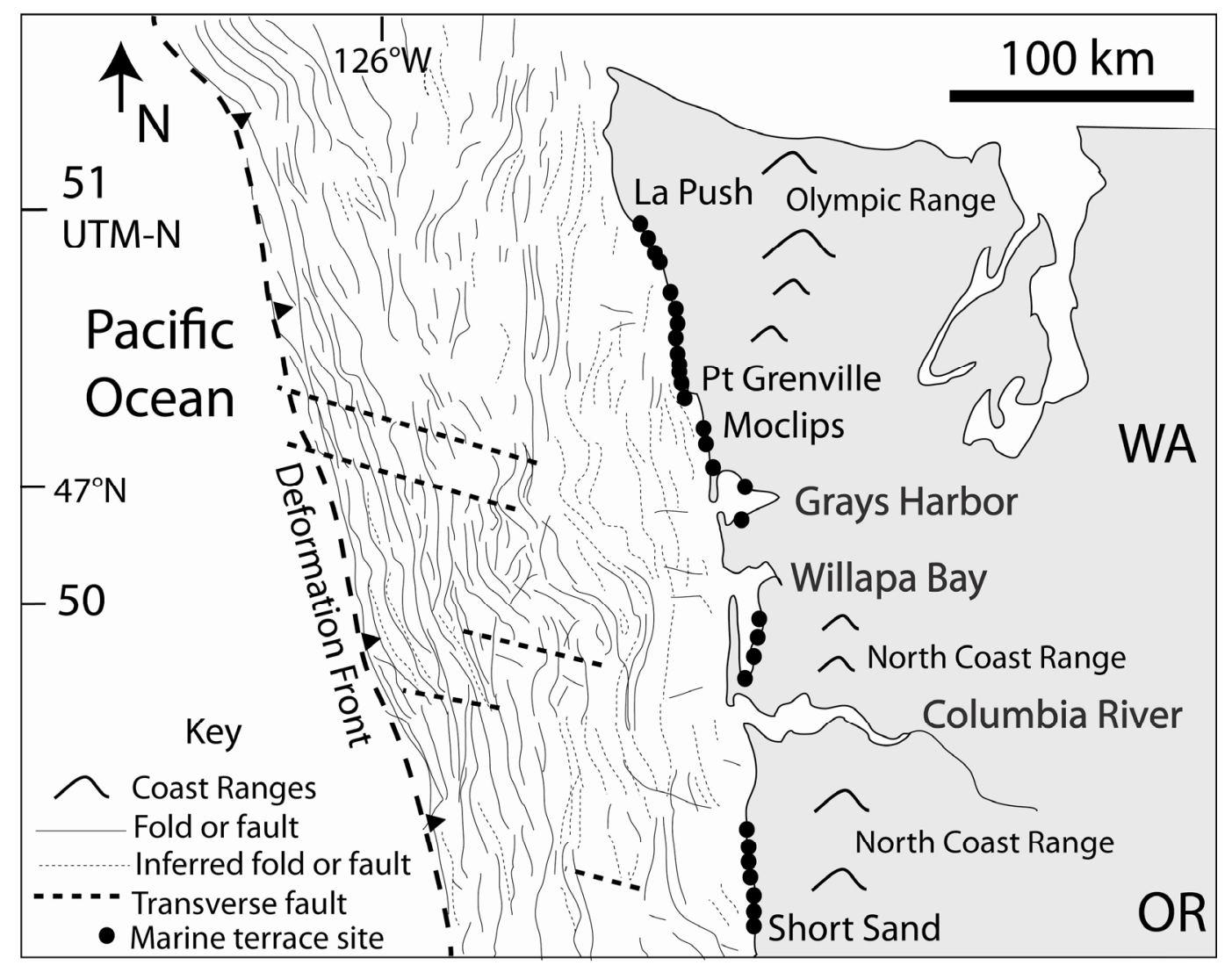

Figure 4. Map of marine terrace sites in Washington and northernmost Oregon

The marine terraces (solid circles) were surveyed for elevation to test the landward extent of the fold and fault belt or deformation belt in the north central Cascadia margin. Offshore Quaternary folds and faults are redrafted from Goldfinger et al. (1992b) as compiled by McNeil et al. (1998).

Local deformation of marine terraces in western Washington could occur from 1) reverse faults or thrusts and/or 2) folds in the deformation belt of the upper-plate. We do not rely on regional trends of marine terrace uplift that could be influenced by regional post-glacial isostatic rebound (Mosher and Hewitt, 2004) and/or regional tectonic under-plating in the inter-plate coupled zones. Instead we use local variability of terrace elevations, which correspond to smaller scale vertical deformation (1-10s km along-shore distance) from active Quaternary 
faults and folds that are generally oriented sub-parallel to the shoreline. To compare along-margin changes in vertical deformation we use grouped marine terraces of similar age, either from the MIS-5 or MIS-7 marine high-stands. Mid-stage age estimates of 110 and $220 \mathrm{ka}$, respectively, are used for the undifferentiated MIS-5 terraces and the undifferentiated MIS-7 terraces. Sea cliff or bay terrace deposit elevations were surveyed into predicted tide level by theodolite or EDM total station (Peterson et al., 1994). Surveyed terrace platform or basal beach deposits are reported relative to mean sea level $( \pm 0.5 \mathrm{~m} \mathrm{MSL})$ which is about one meter above the regional NAVD88 0 m datum.

Tidal wetland records of gradual marsh emergence and abrupt marsh submergence in some subduction zones are related to tectonic strain cycles of interseismic uplift and coseismic subsidence, respectively (Figure 3) (Plafker, 1972; Ovenshine et al., 1976). In the central Cascadia margin these records have been used to establish megathrust ruptures (Atwater, 1987; Darienzo \& Peterson, 1990) and rupture event recurrence intervals (Darienzo \& Peterson 1995; Atwater \& Hemphill-Haley, 1997). A well reported record of coseismic subsidence events that occurred in the north central Cascadia margin during the last 3,000 $\mathrm{yr}$ comes from the Niwiakum locality (Niaw) in Willapa Bay, Washington (Figure 5) (Atwater et al., 2004). A total of five subsidence events during the last $\sim 2.6 \mathrm{ka}$ are recorded at the Niwiakum locality in Willapa Bay.

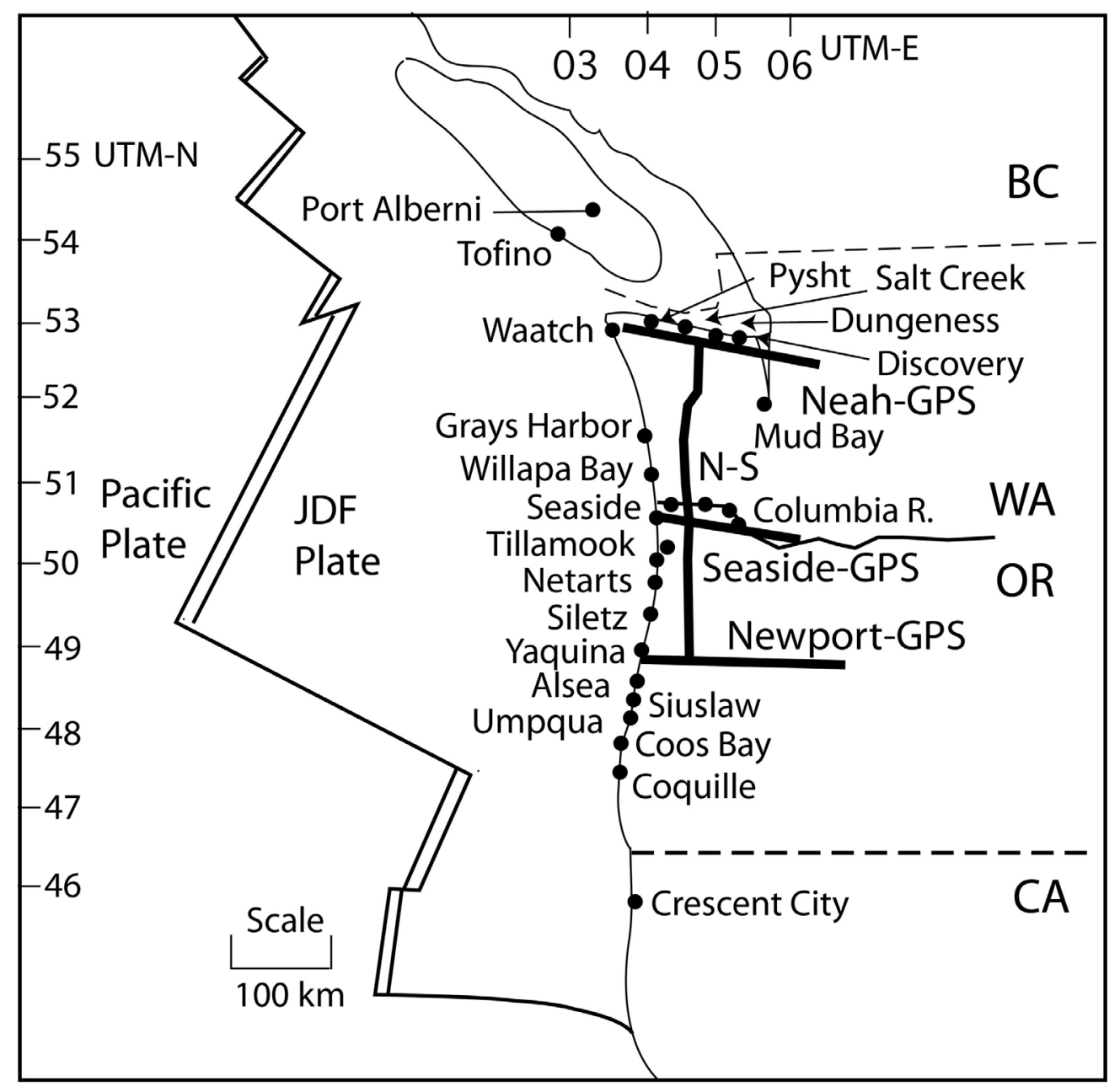

Figure 5. Map of tidal marsh localities and new GPS strain baselines

Tidal marshes (solid circles) were used to establish conditions of late Holocene coseismic subsidence during the last 2,600 yr (most sites). GPS strain baselines established for this study (bold lines) include three across-margin traverses (Neah, Seaside, and Newport) and one along-margin traverse (N-S).

The magnitude of paleosubsidence in the central Cascadia margin can be established from in-situ plant macrofossils and/or microfossil indicators of paleotidal level (Darienzo \& Peterson, 1990; Hemphill-Haley, 
1995; Shennan et al., 1996; Barnett, 1997). Freshwater tidal settings in the Columbia River and the upper Waatch wetlands (Figure 1) preclude the use of saline microfossil indicators in some settings in this comparative study. In this paper the presence and/or relative abundance of plant macrofossils are used to establish three conditions of paleosubsidence including 1) less than $0.5 \mathrm{~m}$ subsidence, 2) $1.0 \pm 0.5 \mathrm{~m}$ subsidence, and 3) greater than $1.5 \mathrm{~m}$ subsidence. The paleotidal level indicators, in order, from lowest to highest paleotidal level, are as follows: a) mud and/or slightly rooted mud ( $0 \mathrm{~m}$ mean tidal level), b) peaty mud, c) muddy peat, and d) peat/in-situ stump or oxidized paleosol (2.0 m mean tidal level) (Peterson et al., 2000). These macrofossil paleosubmergence indicators have been tested and calibrated against microfossil (diatom) indicators of paleosubmergence in the same core intervals in tidal marshes from Grays Harbor, WA, Seaside, OR, Tillamook Bay, OR, and Siletz Bay, OR (Figure 5) (Barnett, 1997).

An abrupt and sustained submergence that includes a transition across at least two paleotidal level indicators represents a significant paleosubsidence event of at least $0.5 \mathrm{~m}$ of sea level rise. A lack of at least two significant subsidence events during the last 2,600 yr represents site proximity to a zero-isobase (Figure 3). An abrupt upcore transition from the highest paleotidal indicator (peat/stump) to an overlying mud (lowest paleotidal indicator) represents at least $1.5 \mathrm{~m}$ of subsidence. The paleotidal level indicators used here are appropriate for reconnaissance level subsidence mapping and they can be used in freshwater tidal marsh systems in the central Cascadia margin (Peterson et al., 2012a). The macrofossil paleosubsidence indicators, as detailed above, have been widely tested in 60 marsh core sites from 10 tidal marsh localities in northwest Oregon and southwest Washington (Peterson et al., 1997). The testing showed that 1) the AD 1700 subsidence horizon was found at every test site and 2) no subsidence events $(>0.5 \mathrm{~m})$ were found above or after the AD 1700 event horizon, as established by radiocarbon dating and/or paleotsunami deposit correlation.

Global positioning system (GPS) station baselines are evaluated for across-margin (west-east) and along margin (north-south) components of modern horizontal strain in the central Cascadia margin. Four baseline traverses are selected at 1) the middle of the central Cascadia margin at Seaside, OR, 2) the northern end of the north central Cascadia margin at Neah Bay WA, and 3) a representative traverse across the south central Cascadia margin at Newport, OR, and 4) a north-south baseline traverse that approximately bisects the across-margin baseline traverses (Figure 5). The GPS stations that are used in the baseline strain analyses are part of a large network that covers the Cascadia margin study area (PNGA 2013; NOAA, 2013).

GPS data were obtained as follows "Receiver data files (RINEX format) were provided by the Pacific Northwest Geodetic Array, Central Washington University (http://www.geodesy.cwu.edu/) (PNGA, 2013), and NOAA's CORS data site (http://geodesy.noaa.gov/CORS/) (NOAA, 2013). Precise ephemerides were provided by NOAA CORS (http://geodesy.noaa.gov/CORS/). The GPS Toolkit (Tolman et al., 2004) was used to process the vector distance between the two stations. The time-series for baseline vector length was then smoothed with a moving average filter before best-fitting a linear trend (R Core Team, 2012) and the annual strain rate computed if there was a significant trend (alpha < 0.05)" (PNGA, 2013). We use analysis of variance (ANOVA) to verify that that the computed strain rate is statistically valid (alpha $=0.05$, where the null hypothesis is that the regression slope is zero). The computational processing efforts for the measurement and statistical evaluation of the GPS baseline strain analyses are substantial. Three multi-core PC machines were operated nearly continuously for one year to process the strain data from the 27 GPS stations that are presented in this paper.

\section{Results}

\subsection{Late Quaternary Deformation of Pacific Coast Marine Terraces}

Sixteen sea cliff terrace profiles between Point Grenville and La Push, in the central coast of Washington yield elevations from the MIS-5 terraces or the MIS-7 terraces. To establish the long-term variability of local vertical deformation we group the heights of the MIS-5 terraces (mid-stage age of $110 \mathrm{ka}$ ) and take one half the measured heights of the MIS-7 terraces (mid-stage age of $220 \mathrm{ka}$ ), based on an assumption of relatively constant long-term deformation during the last 200,000 yr. The MIS-5 terrace heights and the one half heights of the MIS-7 terraces range from 4 to $12 \mathrm{~m}$ above mean sea level (MSL) (Table 1; Figure 6). The mean and 1-sigma standard deviation values of the wave cut platforms from the central Washington coast are 7.6 $\pm 2.1 \mathrm{~m}$. Sixteen sea cliff and bay cliff profiles between Moclips, Washington, and Short Sands Beach, Oregon, referred to here as the south Washington coast, yield elevations of MIS-5 wave cut platforms and highest correlative tidal deposits that range from 5 to $13 \mathrm{~m}$ MSL. The mean and 1-sigma standard deviation values of the high-stand deposits from the south coast are $8.8 \pm 2.6 \mathrm{~m}$. 
Table 1. Latest Pleistocene marine terrace elevations in Washington State

\begin{tabular}{|c|c|c|c|c|c|c|}
\hline Name & $\begin{array}{c}\text { UTM } \\
\text { Northing } \\
(\mathrm{m})\end{array}$ & $\begin{array}{l}\text { Setting } \\
\text { feature }\end{array}$ & $\begin{array}{c}\text { Marine } \\
\text { Terrace } \\
\text { (m MSL) }\end{array}$ & Age & $\begin{array}{c}\text { Outwash } \\
\text { plain } \\
\text { (m MSL) }\end{array}$ & $\begin{array}{c}\text { Distance to } \\
\text { deformation } \\
\text { front }(\mathrm{km})\end{array}$ \\
\hline N2ndBeach & 5305000 & $\mathrm{SC} / \mathrm{WP}$ & 9 & $85-130(1)$ & 24 & 128 \\
\hline S2ndBeach & 5304700 & SC/WP & 9 & $85-130(1)$ & 28 & 129 \\
\hline N3rdBeach & 5304100 & SC/WP & 8 & $85-130(1)$ & 32 & 128 \\
\hline S3rdBeach & 5303650 & SC/WP & 9 & $85-130(1)$ & 32 & 130 \\
\hline S.HohOxbo & 5289000 & SC/WP & 12 & $\sim 85$ (2) & 17 & 140 \\
\hline Ruby & 5285000 & $\mathrm{SC} / \mathrm{WP}$ & 8 & $\sim 85$ (2) & 13 & 139 \\
\hline BeachTr4 & 5282000 & SC/WP & 6 & $\sim 85$ (2) & 16 & 138 \\
\hline Beach4 & 5278000 & $\mathrm{SC} / \mathrm{WP}$ & 5 & $\sim 85$ (2) & 14 & 138 \\
\hline Kalaloch & 5274000 & $\mathrm{SC} / \mathrm{WP}$ & 4 & $\sim 85$ (2) & 9 & 137 \\
\hline S.Queets & 5269000 & $\mathrm{SC} / \mathrm{WP}$ & 6 & $\sim 85$ (2) & 11 & 137 \\
\hline N.Whale & 5261000 & SC/WP & $14 / 7 *$ & $273(2)$ & 16 & 136 \\
\hline S.Whale & 5259000 & SC/WP & $10 / 5^{*}$ & $274(2)$ & 19 & 136 \\
\hline L.Hogsback & 5254000 & SC/WP & $16 / 8^{*}$ & $275(2)$ & 27 & 137 \\
\hline Pratt & 5248000 & SC/WP & $18 / 9^{*}$ & $276(2)$ & 29 & 135 \\
\hline N.Quinault & 5247000 & SC/WP & $20 / 10^{*}$ & 277 (2) & 37 & 136 \\
\hline Pt Grenville & 5240000 & SC/WP & $14 / 7 *$ & 277 (2) & 24 & 137 \\
\hline Moclips & 5232000 & SC/WP & 5 & $85-130(3)$ & & 142 \\
\hline Highland & 5230000 & SC/WP & 5 & $85-130(3)$ & & 143 \\
\hline Copalis & 5218500 & $\mathrm{BC} / \mathrm{LG}$ & 8 & $85-130$ & & 145 \\
\hline Neds & 5204000 & $\mathrm{BC} / \mathrm{TF}$ & 9 & $85-130$ & & 146 \\
\hline Ocosta & 5193000 & $\mathrm{BC} / \mathrm{TF}$ & 12 & $85-130$ & & 145 \\
\hline Copper Pt & 5159000 & $\mathrm{BC} / \mathrm{TF}$ & 9 & $85-130$ & & 148 \\
\hline Ramsey Pt & 5157000 & $\mathrm{BC} / \mathrm{TF}$ & 8 & $\sim 85$ (4) & & 148 \\
\hline Pickernell & 5156000 & $\mathrm{BC} / \mathrm{TF}$ & 7 & $\sim 85$ (4) & & 147 \\
\hline Long Beach & 5134000 & $\mathrm{BC} / \mathrm{TF}$ & 8 & $85-130$ & & 138 \\
\hline Indian & 5087000 & $\mathrm{SC} / \mathrm{LG}$ & 13 & $85-130(5)$ & & 118 \\
\hline Cannon & 5080000 & $\mathrm{SC} / \mathrm{LG}$ & 11 & $85-130(5)$ & & 119 \\
\hline Arcadia & 5077000 & $\mathrm{SC} / \mathrm{LG}$ & 8 & $85-130(5)$ & & 119 \\
\hline Hug Point & 5075000 & $\mathrm{SC} / \mathrm{LG}$ & 13 & $85-130(5)$ & & 119 \\
\hline Arch Cape & 5074000 & $\mathrm{SC} / \mathrm{LG}$ & 6 & $85-130(5)$ & & 119 \\
\hline Cove & 5071000 & $\mathrm{SC} / \mathrm{LG}$ & 11 & $85-130(5)$ & & 118 \\
\hline Short Sand & 5067000 & $\mathrm{SC} / \mathrm{LG}$ & 8 & $85-130(5)$ & & 117 \\
\hline
\end{tabular}

Notes: Terrace high stand ages or equivalent marine isotope stages (MIS) are from: (1) Heusser (1977), (2) Thackray (1998), (3) Vanderburgh et al. (2010), (4) Clifton (1994), and (5) Mulder (1992). Undifferentiated MSI-5 terraces are shown with the full age span (85-130 ka) (Specmap, 2013). Terrace heights from the older MSI-7 (200-240 ka) are shown as elevation/2=height $(*)$. These one-half elevations as calibrated to MSI-5 uplift rate, assuming constant uplift rates for the MIS-5 and MIS-7 terraces. Cooper Pt and Ramsey Pt were resurveyed (2012) to adjust (subtract) for post-high stand loess caps (several meters in thickness (Peterson et al., 2014). Distance to the buried trench or deformation front $(\mathrm{km})$ is taken east-west. 

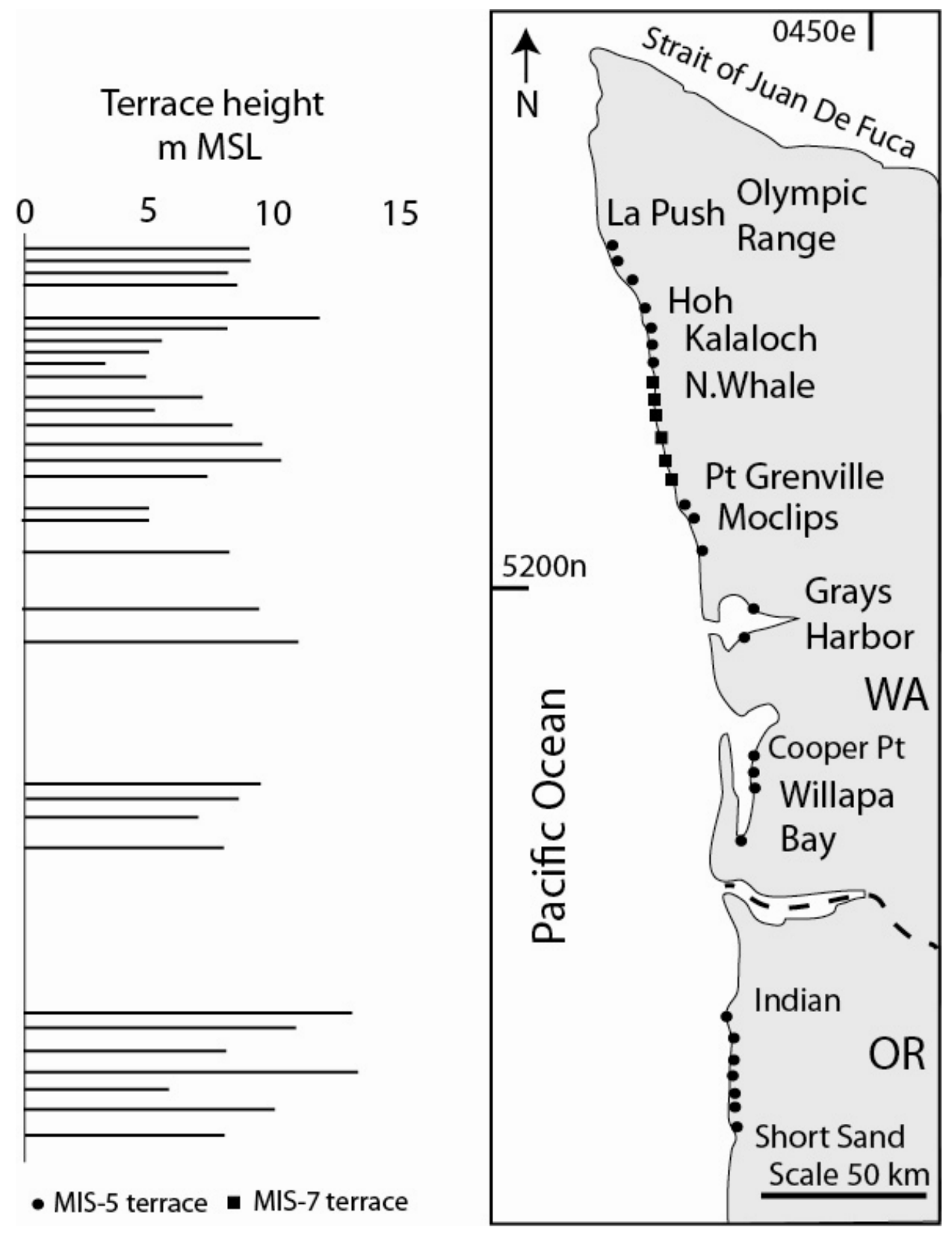

Figure 6. Elevations of wave cut platforms and high-stand bay tidal deposits

Marine terrace sections are exposed in sea cliffs or bay cliffs, as shown for central and south Washington and northernmost Oregon. Marine terrace platforms were surveyed into predicted mean sea level (MSL) using a theodolite EDM total station (error $\pm 0.5 \mathrm{~m}$ ) [Peterson et al., 1994]. Elevations of the MIS-7 terraces (200-240 ka) located between NWhale and Pt Grenville are shown at one half height to compare to the remaining MIS-5 terraces $(85-130 \mathrm{ka})$. Data are from Table 1.

The relatively low elevations of the MIS-5 and MIS-7 terraces in central Washington (Table 1) were unexpected, based on regional neotectonic compilations by West and McCrumb (1988). Thick glacial outwash and loess deposits mantle the marine terrace surfaces (Table 1) (Rau, 1973, 1979; Thackray, 2001) leading to possible overestimation of terrace heights based on topographic maps. A second misleading factor is the pristine condition of the older and wider MIS-7 terraces (200-240 ka), which were well preserved under glacial outwash deposits. Low uplift rates permitted the high wave energy of the Washington coast to locally erode the narrow MIS-5 terraces, leaving the pristine MIS-7 terraces to be misidentified as MIS-5 terraces. The correct ages of the older MIS-7 terraces in the central Washington coast (Table 1) were established by optically stimulated luminescence (OSL) dating (Thackray, 1998). 


\subsection{Holocene Tidal Marsh Records of Cyclic Coseismic Subsidence}

Freshwater tidal marsh records of abrupt paleosubsidence have been used to establish the trough of coseismic subsidence in the lower Columbia River Valley (Figures 5 and 7) (Peterson et al., 2000). Paleotsunami sand sheets accompany abrupt subsidence events in the lowest reaches of the Lower Columbia River Valley at site L\&C. Maximum subsidence values $(>1.5 \mathrm{~m})$ occur between sites JohnD and BlindS in the lower Columbia River Valley (Peterson et al., 2012a). The landward limit of cyclic subsidence, including two weak events $(\sim 0.5 \mathrm{~m}$ subsidence) since about 2,800 yr BP occurs at site Crlv2 at Longview, Washington. Adjacent site Crrf1 shows no subsidence, nor do two landward sites (Crdi2 and Crwl) that are dated to about $1.3 \mathrm{ka}$ by terphrochronology (Peterson et al., 2012b).

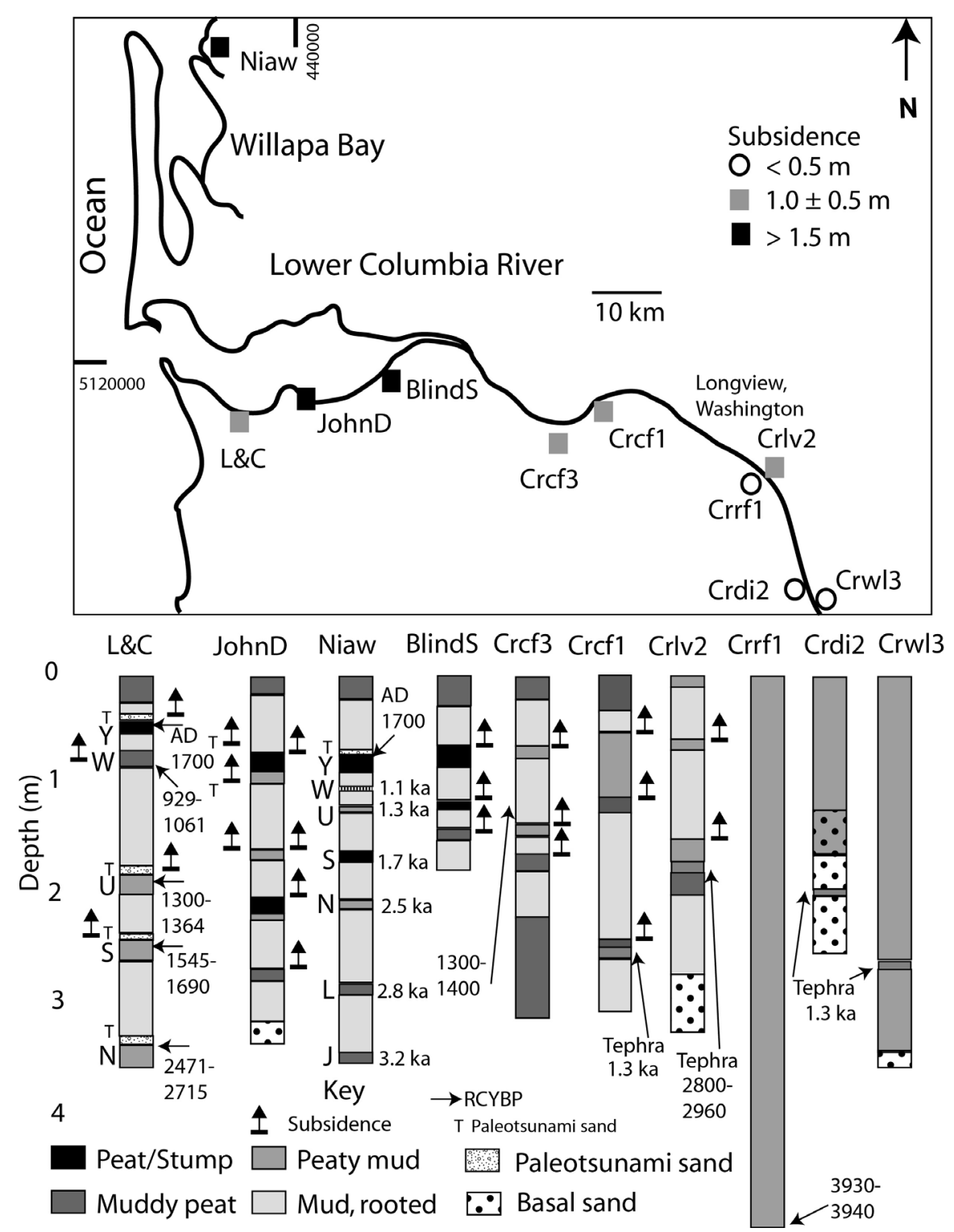

Figure 7. Core sites and corresponding core logs in the lower Columbia River

Core logs show paleosubsidence events (vertical arrows) in the lower Columbia River tidal wetlands, and in Willapa Bay (Figure 1). See text for lithology and plant macrofossil indicators. Subsidence events and radiocarbon dates from the Niawiakum tidal creek in Willapa Bay (Niaw) are from Atwater et al. (2004). Subsidence events and radiocarbon dates from the Lewis and Clark tidal creek (L\&C) near the mouth of the Columbia River are from Jurney (2001). Core sites JohnD and BlindS were first identified in Peterson et al., (2000). New core logs are shown for the uppermost reaches of the middle Columbia River valley (Crrf1, Crdi2, and Crwl3) using dated tephra layers (1.3-3.0 ka) (Peterson et al., 2012b). The remaining core logs are redrawn from Peterson et al. (2012a). 


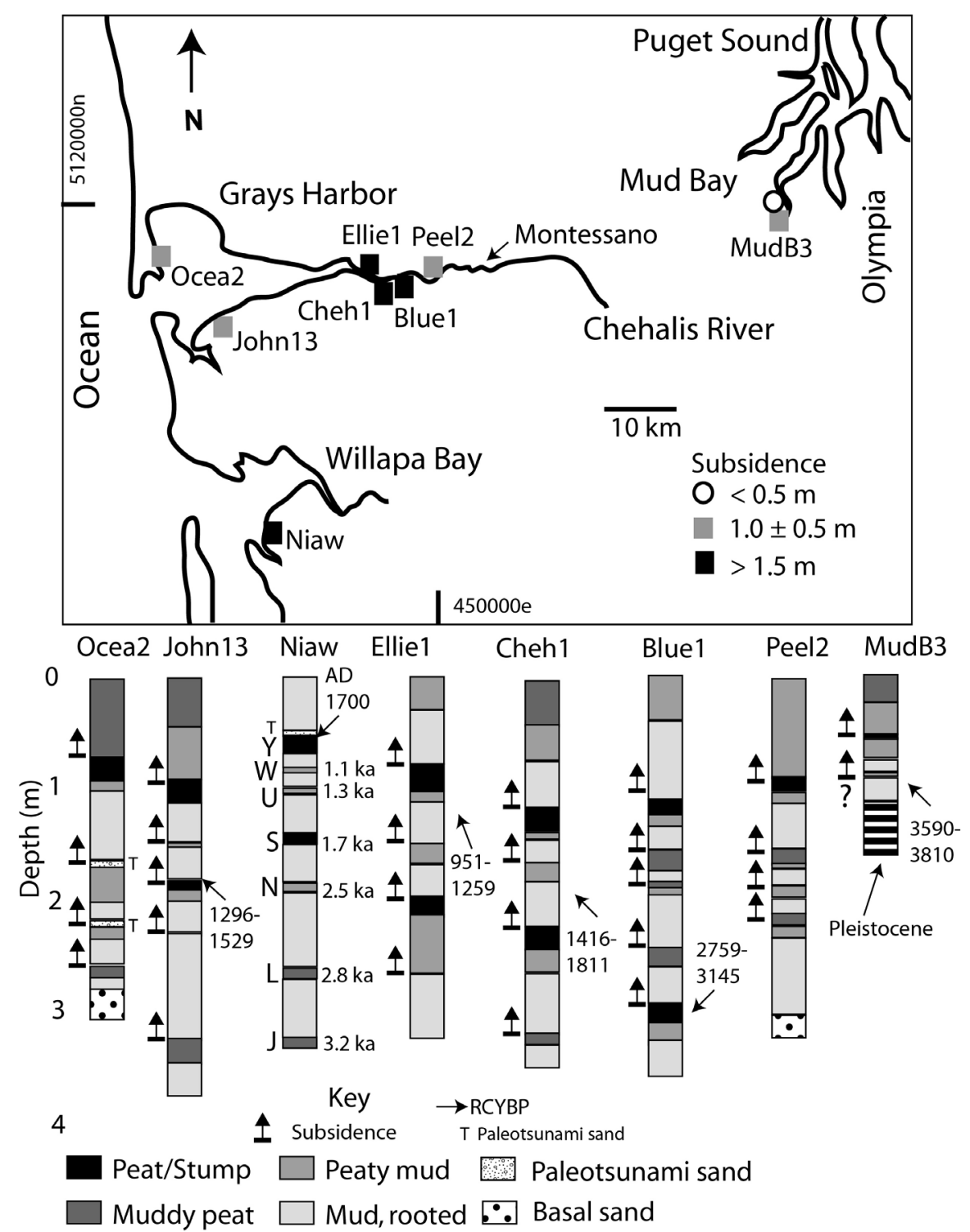

Figure 8. Core sites and corresponding core logs in the Grays Harbor transect

Core logs show paleosubsidence events (vertical arrows) in the Grays Harbor and Chehalis River tidal wetlands. Basal conventional radiocarbon dates from John13, Ellie1, Cheh1, Blue1 (Atwater, 1992) have been calibrated here using CALIBv6 (Stuiver et al., 2012). Subsidence estimates for the last Cascadia event (AD 1700) were previously established for Ocea2, John13, Ellie1, Cheh1, Blue1 (Barnett, 1997; Peterson et al., 2000). Core logs from Ocea2, John13, and Ellie1 are from Barnett (1997). Core sites Cheh1 and Blue1 were re-logged by these authors in 2012. A new site, Peel Slough (Peel2) (coordinates UTMe451380, UTMn5200490), was cored and logged by these authors in 2012. The Mud Bay site, (MudB3) (coordinates UTMe501070, UTMn5210150), was logged by these authors in 2011. It was initially identified and recommended to these authors by D.R. Croes (pers. comm. 2009). 
Tidal marshes in the lowest reaches of Grays Harbor record multiple subsidence events (Atwater, 1992; Shennan et al., 1996; Atwater, 1997) and associated paleotsunami sand layers at site Ocea2 (Figures 5 and 8). Microfossil (diatom) paleotidal indicators independently confirmed paleosubsidence (at least $1.0 \mathrm{~m}$ sea level rise) at two sites John13 and Elli1 for the last Cascadia event (AD 1700) in Grays Harbor (Barnett, 1997). The trough of maximum coseismic subsidence in the Grays Harbor traverse, that is $2-3$ events showing at least $1.5 \mathrm{~m}$ subsidence, occurs between sites Elli1 and Blue1. Subsidence values appear to diminish slightly with distance landward at site Peel2, but they could not be reliably traced further east due to the head of tide in the lower Chehalis River Valley at Montessano, WA. The next tidewater setting to the east of the lower Chehalis River Valley occurs at Mud Bay, WA, where one weak subsidence event ( $>0.5 \mathrm{~m}$ subsidence) and another possible subsidence event ( $<0.5 \mathrm{~m}$ subsidence) are found at site Mud3 since 3590-3810 yr BP (Table 2). Adjacent core sites only demonstrated one subsidence event in the tidal marsh sections (1.5 m depth) in Mud Bay. We place the landward limit of cyclic subsidence, which is to say at least two subsidence events of at least $0.5 \mathrm{~m}$ subsidence within 2,600 yr, at Mud Bay, Olympia, Washington. Future work might reveal additional subsidence sites and/or events in the Puget Sound tidal waters, though it could be difficult to discrimination between Cascadia ruptures and local fault displacements in the Puget forearc valley (Bucknam et al., 1992; Fisher et al., 2005).

Table 2. New radiocarbon dates from buried marsh samples in Mud Bay and the Strait of Juan de Fuca

\begin{tabular}{llllll}
\hline Locality & Depth cm & Material & Adjusted & Calibrated 2 $\sigma$ & Beta \\
\hline Mud Bay 3 & 95 & peat & $3420 \pm 30$ & $3590-3810$ & 344130 \\
Salt Creek CB & 55 & peat & $1790 \pm 30$ & $1620-1820$ & 322471 \\
Salt Creek CB & 69 & wood & $2440 \pm 30$ & $2360-2700$ & 322472 \\
Pysht 1_72 & 72 & wood & $640 \pm 30$ & $550-670$ & 321560 \\
Pysht 5_83 & 83 & wood & $3670 \pm 40$ & $3890-4090$ & 319838 \\
\hline
\end{tabular}

Notes: AMS radiocarbon dates were provided by Beta Analytic Inc., Miami, Florida.

The Strait of Juan de Fuca provides an exceptional tidal level datum to record paleosubsidence events landward of the coast at the northern end of the north central Cascadia margin (Figure 5). The post-glacial isostatic rebound in the Strait of Juan de Fuca coast (Mosher \& Hewitt, 2004) limits the record of Cascadia subsidence events and associated paleotsunami inundations to latest Holocene time in some tidal marshes. Suitable record lengths are found at the Waatch wetlands, Pysht River, and Salt Creek tidal marshes (Figure 9). Subsidence values for 3-4 events in the Waatch wetlands are estimated to be $0.5-1.0 \mathrm{~m}$ (Peterson et al., 2013b). There is no evidence of coseismic uplift in the Waatch tidal wetlands that could have indicated an onshore (landward) position of first zero-isobase under the Olympic Range.

With increasing distance landward from the Waatch wetlands the apparent subsidence events of at least $0.5 \mathrm{~m}$ abrupt submergence diminish to only two events since 3890-4140 yr BP at the Pysht River marsh and one event, or possibly two events, at the Salt Creek marsh since 2360-2700 yr BP (Table 2; Figure 9). Discovery Bay does not contain any apparent subsidence events since 2,500 yr BP (Williams et al., 2005) and only one possible subsidence event of at least $0.5 \mathrm{~m}$ submergence was found in the very small marsh at Dungeness Bay (DunB 5). We split the distance between Salt Creek and Discovery Bay to place the landward limit of cyclic subsidence, or the second zero-isobase at Dungeness Bay in the Strait of Juan de Fuca. 


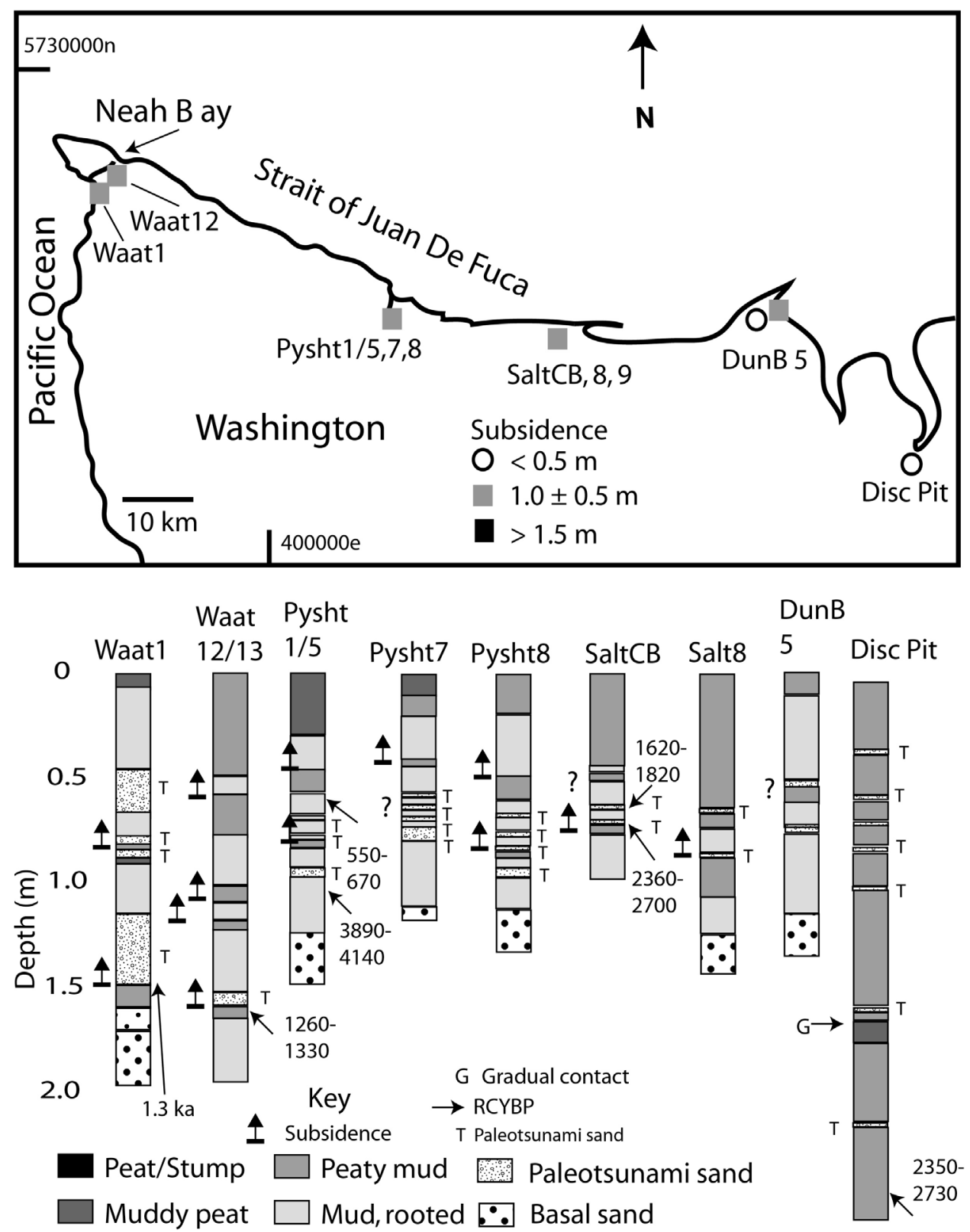

Figure 9. Core sites and corresponding core logs in the Strait of Juan de Fuca transect

Core logs show paleosubsidence events (vertical arrows) in the Waatch, Physt River and Salt Creek tidal wetlands. Subsidence events and radiocarbon dates in the Waatch Valley wetlands (Waat1a and Waat13) are from Peterson et al. (2013b). Core logs and radiocarbon dates from the Salt Creek wetlands (SaltCB, Salt8 and Salt9) (coordinates UTMe447450, UTMn5334200) have been published by Hutchinson et al. (2013). Core logs from the Pysht River marsh (Pysht1/5, Pysht7 and Pysht8) (coordinates UTMe417400, UTMn5339300) are presented here for the first time. Only one possible subsidence event was observed in DunB 5 from Dungeness Bay (coordinates UTMe486380, UTMn5332600) and no subsidence events were reported by Williams et al. (2005) for Discovery Bay (Disc Pit) since 2,500 yr BP.

\subsection{Modern Strain from GPS Stations}

GPS stations used in this study (number $=30$ ) are evaluated for annual changes in adjacent station-to-station distance, as measured twice daily over periods of several years, providing thousands of paired station positions per baseline (Table 3; Figure 10). The west-east baselines reach about 150-200 km in distance landward from the coastline (Table 4). Baseline shortening is shown by negative change in length (mm per annum) and negative 
annual strain. Baseline lengthening is shown by positive change in length ( $\mathrm{mm}$ per annum) and positive annual strain. Strain is change in length/total length $\left(\right.$ annum $\left.^{-1}\right)$.

Table 3. GPS station position data

\begin{tabular}{|c|c|c|c|c|c|c|}
\hline Station & Start Date & End Date & Latitude $\left(^{\circ}\right)$ & Longitude $\left({ }^{\circ}\right)$ & UTM E (m) & UTM N (m) \\
\hline neah & 17-Jan-2005 & 9-Dec-2012 & 48.29773 & -124.62458 & 379514 & 5350668 \\
\hline obec & 24-Mar-2009 & 31-Oct-2012 & 44.06597 & -123.09815 & 492140 & 4879205 \\
\hline blyn & 13-Apr-2007 & 28-Oct-2012 & 48.01583 & -122.92738 & 505415 & 5318062 \\
\hline p367 & 13-Apr-2007 & 6-Nov-2012 & 44.58525 & -124.06157 & 415731 & 4937427 \\
\hline p376 & 8-Jul-2005 & 9-Dec-2012 & 44.94120 & -123.10227 & 491931 & 4976424 \\
\hline chem & 5-May-2007 & 23-Oct-2012 & 48.01054 & -122.77568 & 516730 & 5317496 \\
\hline cush & 1-Jan-2009 & 30-Oct-2012 & 47.42330 & -123.21969 & 483430 & 5252229 \\
\hline hlsy & 27-Feb-2007 & 31-Oct-2012 & 44.37761 & -123.10868 & 491342 & 4913820 \\
\hline lcso & 9-Nov-2005 & 9-Dec-2012 & 44.63400 & -123.10621 & 491576 & 4942299 \\
\hline p374 & 13-Apr-2007 & 6-Nov-2012 & 44.38165 & -123.59023 & 452983 & 4914433 \\
\hline p383 & 22-Oct-2007 & 30-Oct-2012 & 44.34200 & -122.21690 & 562423 & 4910157 \\
\hline p385 & 23-Aug-2007 & 12-Aug-2008 & 44.43485 & -121.94583 & 583898 & 4920713 \\
\hline p387 & 13-Apr-2007 & 6-Nov-2012 & 44.29663 & -121.57429 & 583898 & 4920713 \\
\hline $\mathrm{p} 403$ & 7-Jan-2006 & 15-Nov-2011 & 48.06199 & -124.14042 & 415032 & 5323819 \\
\hline $\mathrm{p} 406$ & 8-Jul-2005 & 9-Dec-2012 & 45.19039 & -123.15197 & 415032 & 5323819 \\
\hline p407 & 13-Apr-2007 & 6-Nov-2012 & 45.95465 & -123.93083 & 427865 & 5089430 \\
\hline p408 & 30-Jun-2005 & 9-Dec-2012 & 46.20045 & -123.37622 & 470974 & 5116388 \\
\hline p409 & 8-Sep-2005 & 9-Dec-2012 & 45.85131 & -123.23917 & 481431 & 5077555 \\
\hline p411 & 13-Apr-2007 & 9-Dec-2012 & 45.53798 & -123.15710 & 487803 & 5077539 \\
\hline p417 & 28-Jun-2005 & 9-Dec-2012 & 46.57445 & -123.29751 & 477203 & 5157919 \\
\hline $\mathrm{p} 418$ & 13-Apr-2007 & 9-Dec-2012 & 47.23635 & -123.40738 & 469166 & 5231510 \\
\hline P423 & 1-Jan-2009 & 9-Dec-2013 & 47.28760 & -122.94077 & 504478 & 5237127 \\
\hline $\mathrm{p} 430$ & 12-Apr-2005 & 9-Dec-2012 & 47.00355 & -123.43582 & 466869 & 5205651 \\
\hline $\mathrm{p} 435$ & 13-Apr-2007 & 9-Dec-2012 & 48.05950 & -123.50304 & 462519 & 5323036 \\
\hline p436 & 13-Apr-2007 & 9-Dec-2012 & 48.04516 & -123.13406 & 490008 & 5321328 \\
\hline p437 & 14-Oct-2008 & 9-Dec-2012 & 48.00173 & -122.45900 & 540355 & 5316634 \\
\hline pkdl & 1-Jan-2009 & 9-Dec-2013 & 45.51818 & -121.56345 & 612196 & 5041519 \\
\hline sthm & 27-Dec-2006 & 30-Oct-2012 & 44.39581 & -122.73379 & 521201 & 4915871 \\
\hline tdls & 1-Jan-2009 & 9-Dec-2013 & 45.60853 & -121.12950 & 645854 & 5052255 \\
\hline weez & 11-Oct-2008 & 5-Aug-2010 & 47.97675 & -122.20446 & 559370 & 5314022 \\
\hline
\end{tabular}

Notes:

Global positioning system (GPS) data for stations used in strain analysis.

Station: 2003jbXXXXXX-ts01.txt GPS station coordinates for sites used in this study.

Start date: year - month - day, Starting date of data used.

End date: year - month - day, Ending date of data used.

Latitude: degrees, latitude of the GPS station, north of equator.

Longitude: degrees, longitude of GPS station east of Greenwich.

UTM E: (m) UTM Zone 10 East coordinate for station

UTM N: (m) UTM Zone 10 North coordinate for station

Station position data are provided in Pacific Northwest Geodetic Array, Central Washington University (http://www.geodesy.cwu.edu/), and NOAA's CORS data site (http://geodesy.noaa.gov/CORS/). 


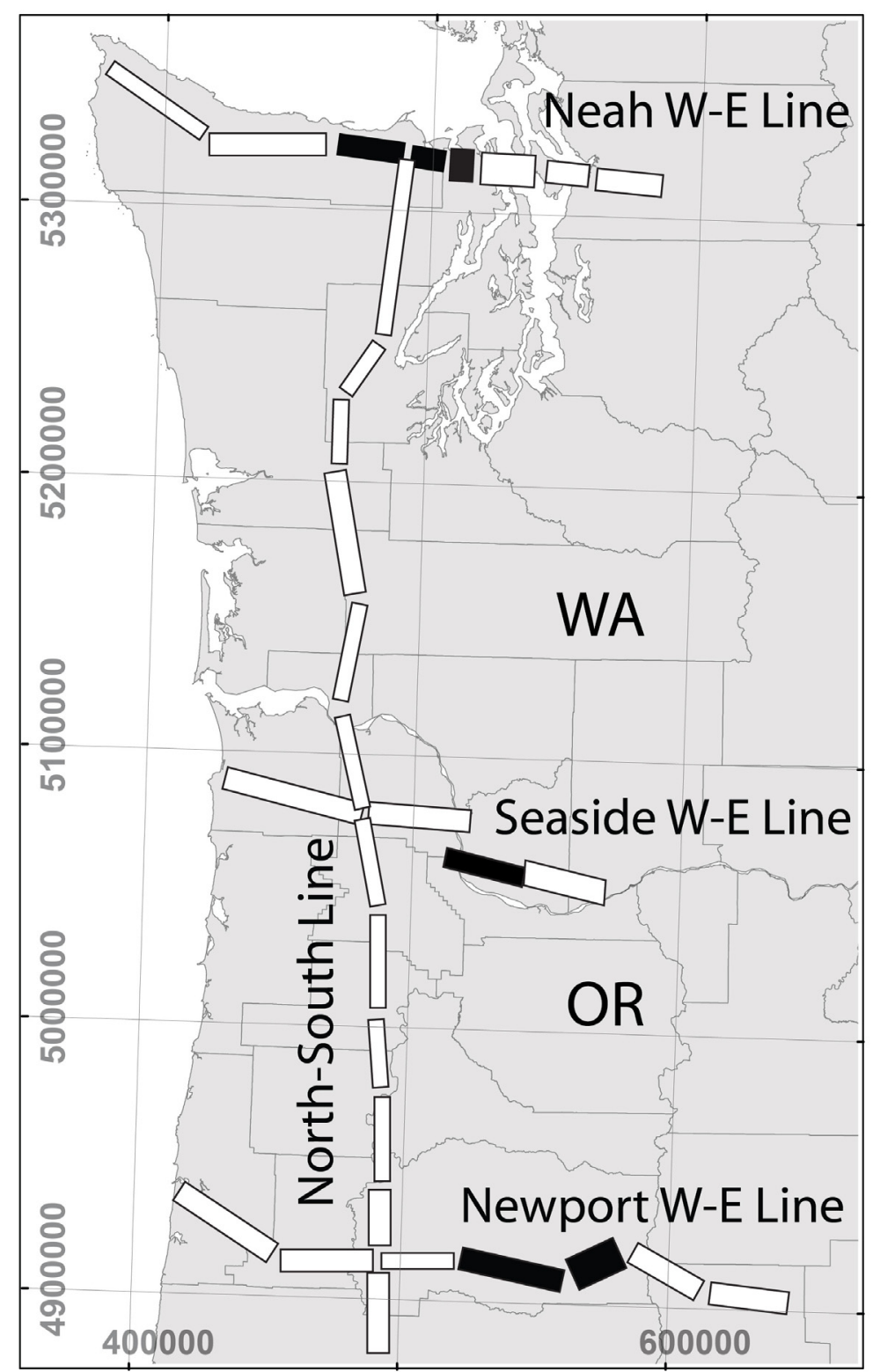

Figure 10. Location map of GPS strain baselines and strain magnitudes

Strain signs and magnitudes (rectangles) shown between GPS stations. Thin lines represent county boundaries in Washington (WA) and Oregon (OR). Relative magnitudes of shortening (open rectangles) and lengthening (black rectangles) are shown by rectangle thickness. GPS station positions (Longitude and Latitude and UTM coordinates) and dates of baseline strain monitoring are shown in Table 3. Baseline strain data are from Table 4. 
Table 4. Strain data for GPS baseline stations in the north central Cascadia margin

\begin{tabular}{|c|c|c|c|}
\hline Baseline & Baseline Length (m) & Change in Length $\left(\mathrm{mm} \mathrm{a}^{-1}\right)$ & Strain Rate $\left(\mathrm{a}^{-1}\right)$ \\
\hline \multicolumn{4}{|l|}{ Neah W-E Line } \\
\hline NEAH - P403 & 44517 & -2.181 & $-4.90 \times 10^{-8}$ \\
\hline $\mathrm{P} 403-\mathrm{P} 435$ & 47527 & -4.943 & $-1.04 \times 10^{-7}$ \\
\hline $\mathrm{P} 435-\mathrm{P} 436$ & 27549 & 4.711 & $1.71 \times 10^{-7}$ \\
\hline P436- BLYN & 15769 & 3.233 & $2.05 \times 10^{-7}$ \\
\hline BLYN- CHCM & 11348 & 17.930 & $1.58 \times 10^{-6}$ \\
\hline $\mathrm{CHCM}-\mathrm{P} 437$ & 23653 & -16.382 & $-1.43 \times 10^{-6}$ \\
\hline P437 - WEEZ & 19192 & -8.387 & $-4.37 \times 10^{-7}$ \\
\hline WEEZ - LKCP & 28155 & -7.039 & $-2.50 \times 10^{-7}$ \\
\hline \multicolumn{4}{|l|}{ Seaside W-E Line } \\
\hline P407 - P409 & 54878 & -6.860 & $-1.25 \times 10^{-7}$ \\
\hline P409- P414 & 42503 & -6.630 & $-1.56 \times 10^{-7}$ \\
\hline P427 - PKDL & 61541 & 2.02 & $3.28 \times 10^{-8}$ \\
\hline PKDL - TDLS & 35305 & -9.65 & $-2.73 \times 10^{-7}$ \\
\hline \multicolumn{4}{|l|}{ Newport W-E Line } \\
\hline P367 - P374 & 43749 & -8.969 & $-2.05 \times 10^{-7}$ \\
\hline P374 - HLSY & 38377 & -4.030 & $-1.05 \times 10^{-7}$ \\
\hline HLSY - STHM & 29944 & -2.497 & $-8.34 \times 10^{-8}$ \\
\hline STHM - P383 & 41664 & 8.666 & $2.08 \times 10^{-7}$ \\
\hline P383 - P385 & 23955 & 35.933 & $1.50 \times 10^{-6}$ \\
\hline P385 - P387 & 33348 & -9.471 & $-2.84 \times 10^{-7}$ \\
\hline P387 - REDM & 34307 & -5.764 & $-1.68 \times 10^{-7}$ \\
\hline \multicolumn{4}{|l|}{ North - South Line } \\
\hline P436 - CUSH & 69451 & -5.112 & $-7.36 \times 10^{-8}$ \\
\hline CUSH - P418 & 25151 & -0.772 & $-3.07 \times 10^{-8}$ \\
\hline $\mathrm{P} 418-\mathrm{P} 430$ & 25971 & -1.402 & $-5.40 \times 10^{-8}$ \\
\hline P430 - P417 & 48857 & -6.107 & $-1.25 \times 10^{-7}$ \\
\hline P417 - P408 & 42037 & -1.951 & $-4.64 \times 10^{-8}$ \\
\hline P408 - P409 & 40241 & -3.481 & $-8.65 \times 10^{-8}$ \\
\hline P409 - P411 & 35404 & -2.546 & $-7.19 \times 10^{-8}$ \\
\hline P411 - P406 & 38636 & -2.415 & $-6.25 \times 10^{-8}$ \\
\hline P406 - P376 & 27970 & -0.526 & $-1.88 \times 10^{-8}$ \\
\hline P376 - LCSO & 34102 & -1.705 & $-5.00 \times 10^{-8}$ \\
\hline LCSO - HLSY & 28536 & -4.138 & $-1.45 \times 10^{-7}$ \\
\hline HLSY - OBEC & 34635 & -16.867 & $-4.87 \times 10^{-7}$ \\
\hline
\end{tabular}

Notes:

GPS station codes are from Pacific Northwest Geodetic Array, Central Washington University (http://www.geodesy.cwu.edu/), and NOAA's CORS data site (http://geodesy.noaa.gov/CORS/).

Approximate GPS station positions (m UTM) and monitoring dates for GPS stations are shown Table 3. 
The three west-east GPS baseline traverses (Figure 10) show significant shortening near the coasts where the negative annual strain rates range from about $-5 \times 10^{-8}$ to about $-1.5 \times 10^{-6}$ (Table 4). The areas of baseline shortening occur within the Coast Ranges, including the Olympic Range in Washington and the North Coast Range in northwest Oregon and southwest Washington (Figure 4). All three west-east baseline traverse in northernmost Washington and northern Oregon, respectively, show lengthening or extension (positive annual strain rates) at about 100 and $150 \mathrm{~km}$ distance from the coast. The extension, ranging from about $1.7 \times 10^{-7}$ to 1.6 $\times 10^{-6}$ annual strain rate occurs in baselines that cross the Puget and Willamette forearc valleys located between the Coast Ranges and the Cascade volcanic arc (Figure 1). The three west-east traverses also demonstrate significant crustal shortening in baselines located at the eastern sides of the forearc valleys. The eastern shortening baselines in central Oregon occur at the western flank of the Cascade volcanic arc.

The north-south baselines, traversing the length of the Olympic and Northern Coast Ranges demonstrate shortening with annual strain rates from about $-2 \times 10^{-8}$ to $-5 \times 10^{-7}$ (Figure 10; Table 4). Overall the west-east shortening rates from the coast across-margin baselines are generally about one order of magnitude larger that those from corresponding along-margin or north-south baselines.

\section{Discussion}

\subsection{Tectonic Symmetry of the Central Cascadia Margin}

The central Cascadia margin is characterized by both 1) symmetry of tectonic features and 2) asymmetry of the neotectonic record settings on either side of its mid-point, at about the position of the lower Columbia River or the border between Washington and Oregon States (Figure 11). The Juan de Fuca plate widths, or west-east distances between the spreading ridge and the deformation front, narrow from a maximum of $420 \mathrm{~km}$ at the midpoint to $240 \mathrm{~km}$ at the boundary with the Explorer plate to the north and to $140 \mathrm{~km}$ at the boundary with the Gorda plate to the south. We assume that descending plate thickness, age, and temperature also vary with approximate mirror-image symmetry as a function of distance along-margin from the midpoint of the central margin.

There are important onshore symmetries in the adjacent North American plate. The Cascade volcanic arc occurs at similar distances of about $350 \mathrm{~km}$ and $300 \mathrm{~km}$ from the deformation front in central Washington and central Oregon, respectively (Figure 11). The distances between the volcanic arc and the deformation front diminish landward of the narrower Explorer plate to the north and the Gorda plate to the south. The large Eocene embayment that preceded infill and uplift of the Coast Ranges is floored by thick Siletz basalt basement reaching several tens of kilometers thickness (Wells et al., 1984; Snavely \& Wells, 1996; Parsons et al., 2005). The Siletz basalt terrane thins and extends about equal distance $(\sim 250 \mathrm{~km})$ north and south from the mid-point of the central margin at the Columbia River. There are variations in apparent plate convergence angle, $45^{\circ}$ to nearly normal, respectively, from south to north, but the greatest change in convergence angle is restricted to the northernmost end of the north central margin (Figure 1), where some convex buckling could be localized (Crosson \& Owens, 1987; Fisher et al., 2005).

There are some asymmetries in Coast Range structures (Figure 11) including thrust faulting in the Olympic Range (Brandon \& Calderwood, 1990; Dragovich et al., 2002) and rotational faulting in the North Coast Range (Wells, 1990). The thrust and rotational faulting were active in Miocene time, but some of the remnant structures could be locally reactivated under Quaternary stress conditions. We suggest that conditions of regional inter-plate coupling and upper-plate bending moments should be approximately symmetrical with distance along-margin on either side of the midpoint of the central margin, at about the position of the lower Columbia River.

In terms of neotectonic records two very important asymmetries occur in the North American plate between the north and south central margins. The coastline diverges from the deformation front, 50 to $140 \mathrm{~km}$ in west-east distance, with increasing along-margin distance from south to north in the central Cascadia margin (Figure 11). The second major asymmetry is the ice sheet glaciation that occurred in western Washington, which locally deepened the Puget forearc valley, but did not occur in the Willamette valley of Oregon. Post-glacial marine submergence of the Strait of Juan de Fuca and the Puget Sound (Mosher \& Hewitt, 2004) resulted in the inland tidewater bodies in the north central margin. The antecedent incised lower Columbia River provides nearly contiguous tidal marsh records of paleosubsidence across the North Coast Range (Figure 11) but no inland tidewater bodies occur south of the Columbia River in the Willamette forearc valley. The Willamette forearc valley lacks tidal water marshes to test for episodic subsidence during late Holocene time. 

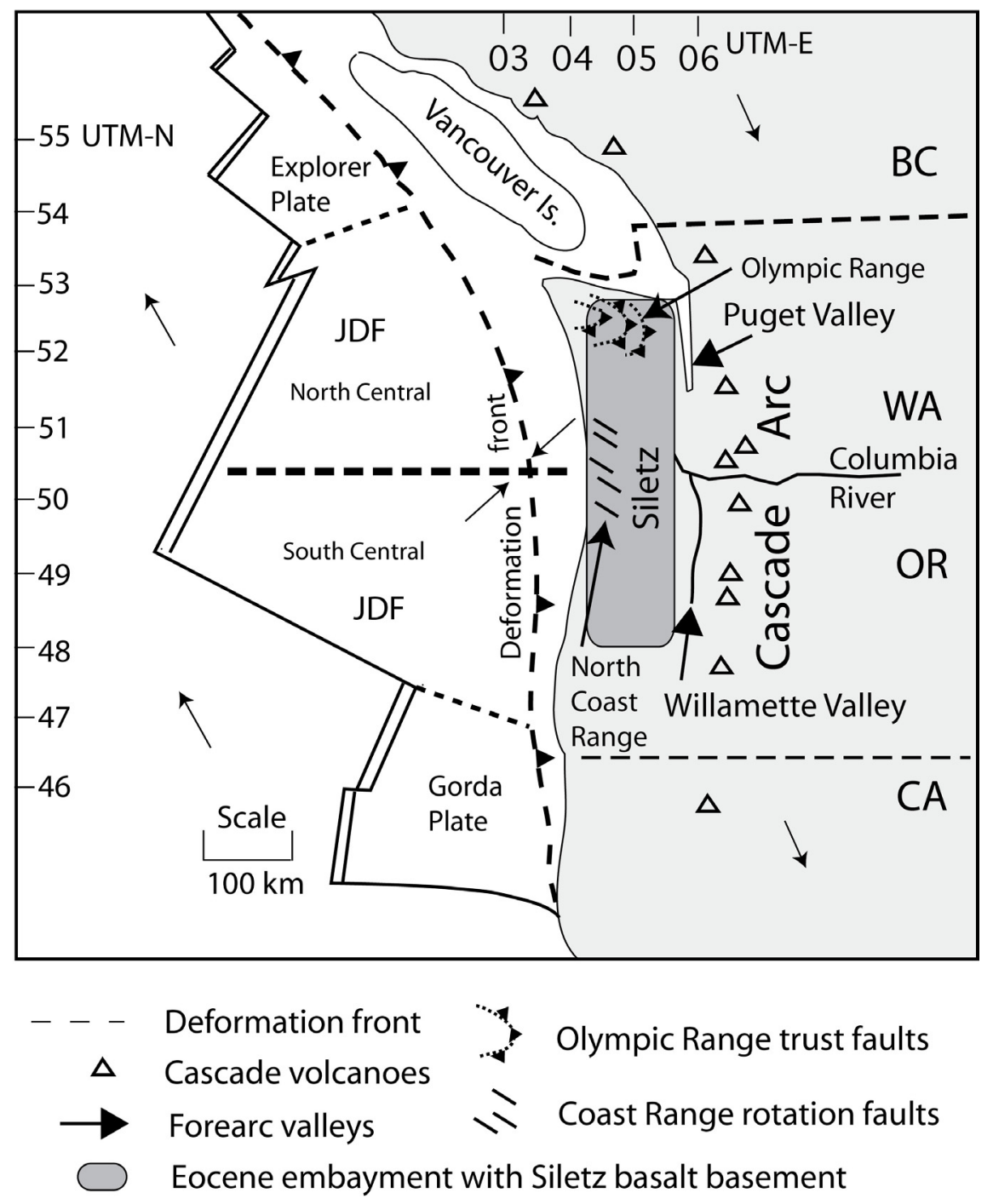

Figure 11. Generalized map of tectonic symmetry in the central Cascadia margin

Map shows apparent symmetry of 1) the Juan de Fuca plate (JDF), 2) the Cascade volcanic arc, and 3) the Eocene embayment with thick Siletz basalt basement, on either side of mid-point at the Columbia River or the boundary between Washington (WA) and Oregon (OR) States. Asymmetries occur in the coastline distances to the deformation front and the distribution of tidewater bodies along the coasts and in the Puget forearc valley, but not south of the Columbia River in the Willamette River forearc valley.

\subsection{Uplifted Marine Terrace Records of Inelastic Vertical Deformation}

Grouped marine terrace elevations are compared between the Washington coasts and selected intervals of the Oregon coast (Table 5). Variability's of terrace elevations for the north and south Washington coasts, $7.6 \pm 2.1 \mathrm{~m}$ and $8.8 \pm 2.6 \mathrm{~m}$, respectively are substantially smaller than variability's of terrace elevations from within the deformation belt in the south Oregon coast $(17 \pm 11 \mathrm{~m}$ and $32 \pm 23 \mathrm{~m})$. An analysis of variance shows that terrace elevations from the Washington coasts are statistically different from the terrace elevations from the deformation belt in the south Oregon coast at the $99 \%$ confidence interval. 
Table 5. Grouped marine terrace elevation data from the Washington and Oregon coasts

\begin{tabular}{lllllc}
\hline $\begin{array}{l}\text { Along coast Interval } \\
\text { UTM-N }\end{array}$ & $\begin{array}{l}\text { Average Position } \\
\text { (UTM-N) }\end{array}$ & $\begin{array}{l}\text { Deform. } \\
\text { Distance }(\mathrm{km})\end{array}$ & $\begin{array}{l}\text { Sample } \\
\text { number }\end{array}$ & $\begin{array}{l}\text { Average } \\
\text { Elevation }(\mathrm{m})\end{array}$ & $\begin{array}{l}\text { Standard } \\
\text { Deviation }( \pm \mathrm{m} 1)\end{array}$ \\
\hline Washington Coast & & & & & \\
$5305000-5240000$ & 5272500 & 137 & 16 & 7.6 & 2.1 \\
$5232000-5067000$ & 5149500 & 143 & 16 & 8.8 & 2.6 \\
Oregon Coast & & & & & \\
$5050000-5008000$ & 5029000 & 110 & 14 & 9.5 & 3.4 \\
$4955000-4918000$ & 4936000 & 101 & 16 & 9.5 & 3.4 \\
$4908000-4812000$ & 4860000 & 95 & 10 & 10.5 & 11.0 \\
$4800000-4763000$ & 4781000 & 75 & 6 & 17.0 & 23.0 \\
$4750000-4733000$ & 4741000 & 56 & 9 & 32.0 & \\
\hline
\end{tabular}

Data from the Washington Coast are from Table 1. Data from the Oregon Coast are from Peterson et al. (2012a). Deformation front distance (Deform. Distance) is the east-west distance $(\mathrm{km})$ to the deformation front. Average elevation (m) is relative to present mean sea level (MSL). Standard deviation of elevation is in meters (m).

Plots of the mean and standard deviation of terrace elevations are shown for the grouped terrace intervals relative to corresponding shoreline distances from the deformation front or the buried trench (Figure 12). The deformation belt does not come ashore in the north central Cascadia margin, where the coastlines are on the order of 130-140 km from the deformation front. Using the relations from the south Oregon coast (Figure 2) it is expected that the fist zero-isobase should also reside offshore of the coast in the north central Cascadia margin.

Though terrace elevations are small in the Washington coast they do represent significant net uplift. The terrace elevations are converted to uplift rate based on marine terrace elevations and ages (Table 1). Mean uplift rates of about $0.1 \mathrm{~mm} \mathrm{yr}^{-1}$ are estimated for the Washington marine terraces, relative to present sea level (Figure 12). The late Quaternary uplift rates of the marine terraces from the south-central Washington coast were not influenced by post-glacial (Holocene) net isostatic adjustments, as based on overlapping sea level curves from Grays Harbor, WA (Peterson et al., 2010) and eustatic sea levels (Flemming et al., 1998), dating back to 12 ka (Figure 12). However, the paleosea-levels at the time of the MIS-5a,c high-stand stages might have been 10-20 m lower than the present Holocene high-stand level (Chappell \& Shackleton, 1986). Regional long-term net uplift rates in the southern Washington coastline and northern Oregon coastline could be $0.1-0.3 \mathrm{~mm} \mathrm{yr}^{-1}$, based on potentially lower sea levels that produced the marine terraces during the later MIS-5 high-stands. Mean uplift rates in the southern Oregon coastline might similarly be increased if lower sea levels are assumed for the MIS5a,c stages, relative to the present sea level.

The relatively low rates of marine terrace uplift in Washington and in northern Oregon, as compared to southern Oregon, correspond to an across-margin width of at least $50 \mathrm{~km}$ (Figure 12). The wide area of lower uplift rates suggests a mechanism of inelastic vertical displacement by regional under-plating above the transition zone, located landward of the strongly coupled zone. The full width of regional Quaternary uplift above the transition zone is not known, but it might be reflected in the net uplift $(1000 \pm 500 \mathrm{~m})$ of marine rocks in the North Coast Ranges (50-75 km in width) after Miocene time (Figure 11) (Niem \& Niem, 1985). It is not known whether the anomalous high elevations of the Olympic Mountains (maximum 2,300 m elev.) in north-westernmost Washington (Figure 4) are due to locally greater Quaternary uplift rates (Pazzaglia \& Brandon, 2001) or to prior uplift during the Miocene period of landward thrust faulting (Brandon and Calderwood, 1990) that was restricted to the Olympic Peninsula (Figure 11). 

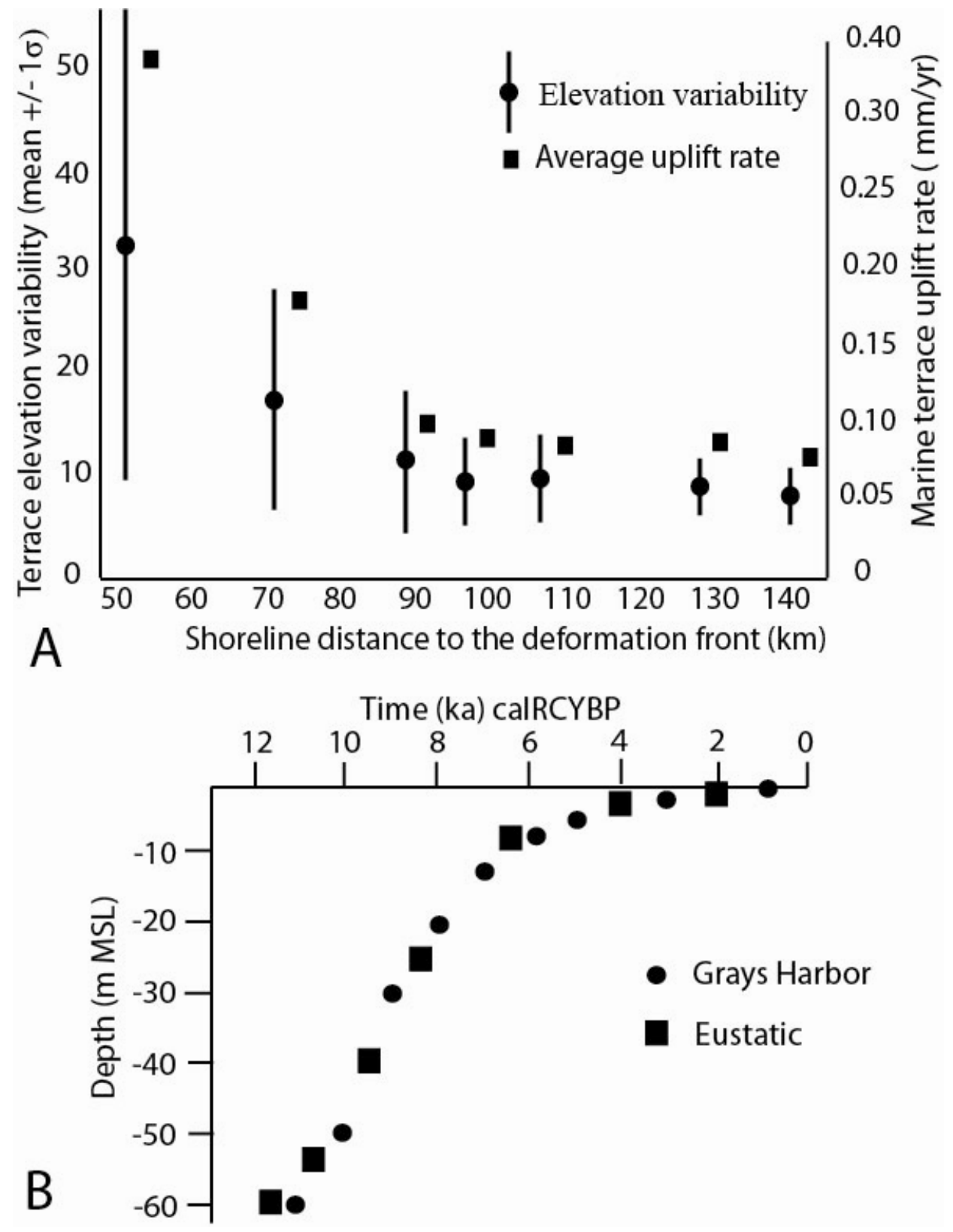

Figure 12. Plots of marine terrace uplift variability in the central Cascadia margin

Part A, plots of marine terrace elevation variability (mean \pm 1 standard deviation) and average terrace uplift rates, based on ages of $85 \mathrm{ka}$ (MIS-5a) or $110 \mathrm{ka}$ (undifferentiated MIS-5) and $220 \mathrm{ka}$ (undifferentiated MIS-7) relative to modern mean sea level with respect to coastline distance from the deformation front. Long-term uplift rates will vary depending on sea level heights during the MIS-5a,c high-stands, probably 10-20 m lower than at present (Chappell and Shackleton, 1986). Terrace elevations from the MIS-7 terraces are taken as one half height to compare to the MIS-5 terrace elevations. Terrace data are from Table 5. Part B, plots of 1) a relative sea level curve from Grays Harbor (solid circles) (Peterson et al., 2010b) and 2) an eustatic sea level curve (solid squares) (Flemming et al., 1998). Uniform overlap of the two curves demonstrates no significant net post-glacial isostatic adjustments in the coastal land levels in the vicinity of Grays Harbor (Point Grenville-Copper Point) (Figure 6) during the last $\sim 12,000 \mathrm{yr}$.

\subsection{Landward and Seaward Limits of Elastic Vertical Deformation Cycles}

Core logs are compiled from representative localities in the study region (Figures 5 and 13; Table 6) that demonstrate one of three paleosubsidence conditions that occurred during the last 1-3 ka. The three paleosubsidence conditions and associated core sites are 1) the seaward limit of paleosubsidence at the first 
zero-isobase (Umpqua River-UR339, Coos Bay-CB478, Crescent City-CCkc5), 2) sites of maximum paleosubsidence in the trough of coseismic subsidence (Tofino-TF, Waatch-WA12/13, Grays Harbor-GHBlue1, Columbia River-CRJohnD, Siuslaw River-SR218b, Coquille-CQ521) and 3) the landward limit of paleosubsidence at the second zero-isobase (Port Alberni-PA5/6/9, Dungeness DunB 5), Mud Bay-MBMudb3, Longview-LVCRlv2). The core logs from Oregon have been previously published (Peterson et al., 2012a) and core logs from Washington are selected from Figures 7, 8, 9.

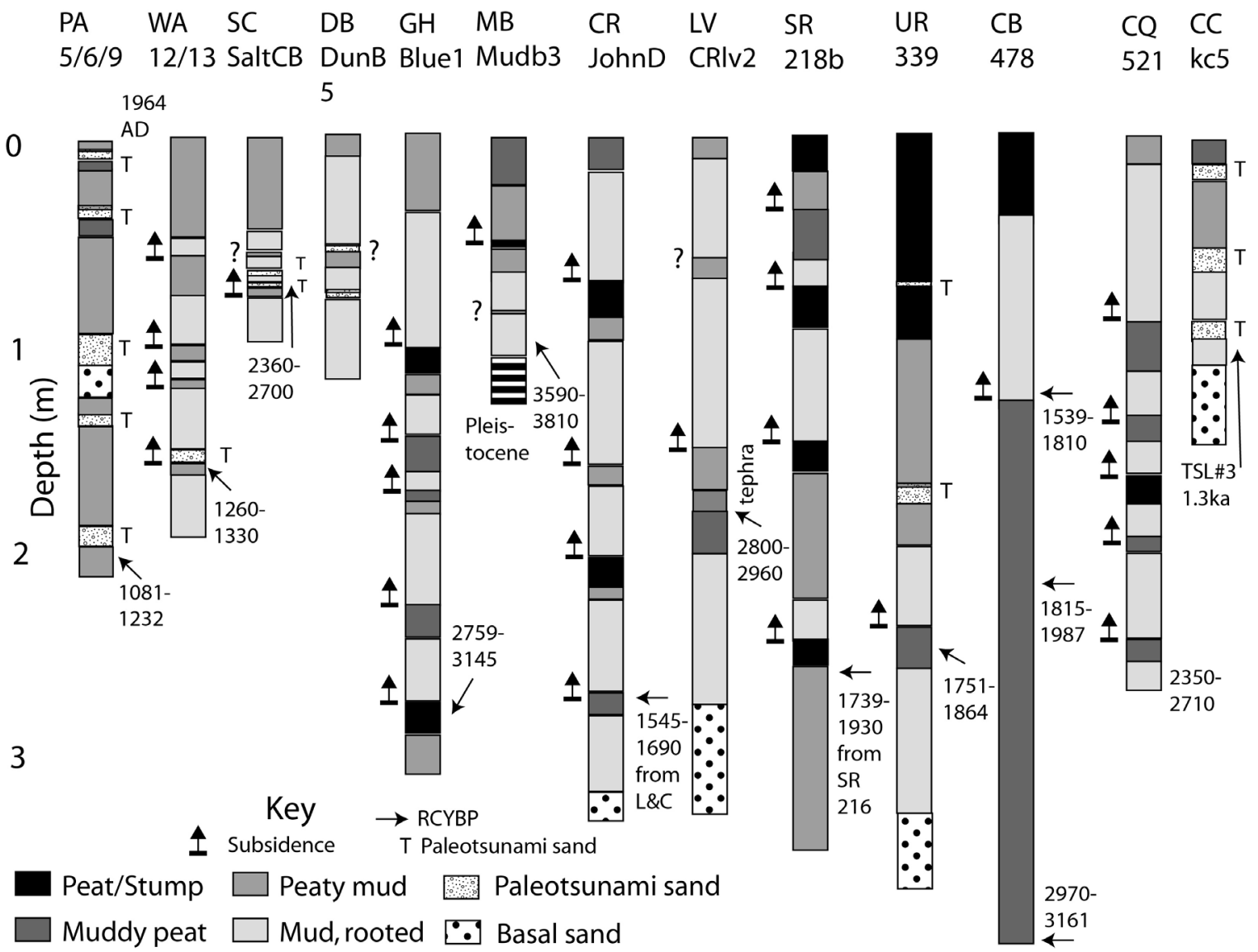

Figure 13. Key core logs showing across-margin limits of cyclic coseismic subsidence

Core $\operatorname{logs}$ are shown for representative sites in across-margin transects that demonstrate 1) the maximum coseismic subsidence (WA, GH, CR, SR, CQ), 2) the landward limit of cyclic subsidence (PA, DB, MB, LV) and 3 ) the seaward limit of cyclic subsidence (UR, CB, CC). See Table 7 for core site position coordinates and data sources. The trough of maximum subsidence is estimated to occur to the east $(\sim 10-30 \mathrm{~km}$ distance) of Coquille, Oregon, but could not be confirmed as the tidal reaches of the Coquille River bend to the south at site Coquille 521. No tidal water bodies extend significantly east of Crescent City (site Crescent City kc5), in northernmost California. 
Table 6. Position coordinates of representative paleosubsidence core sites

\begin{tabular}{lllll}
\hline Locality and core site & $\begin{array}{l}\text { UTMe } \\
(\mathrm{m})\end{array}$ & $\begin{array}{l}\text { UTMn } \\
(\mathrm{m})\end{array}$ & $\begin{array}{l}\text { Paleosubsidence } \\
\text { Condition }\end{array}$ & $\begin{array}{l}\text { Data } \\
\text { source }\end{array}$ \\
\hline Port Alberni PA5/6/9 & 367000 & 5457300 & second zero-isobase & 1 \\
Tofino TF4 & 291800 & 5442100 & Maximum subsidence & 1 \\
Waatch WA12/13 & 379200 & 5357800 & Maximum subsidence & 2 \\
Dungeness Bay 5 & 486380 & 5332600 & second zero-isobase & 3 \\
Grays Harbor Blue1 & 444800 & 5199600 & Maximum subsidence & 3 \\
Mud Bay Mudb3 & 501070 & 5210150 & second zero-isobase & 3 \\
Columbia River JohnD & 442300 & 5114000 & Maximum subsidence & 4 \\
Longview CRlv2 & 500600 & 5110100 & second zero-isobase & 4 \\
Siuslaw River 218b & 431500 & 4874100 & $\sim$ Maximum subsidence & 4 \\
Umpqua River 339 & 405400 & 4836200 & first zero-isobase & 4 \\
Coos Bay 478 & 401100 & 4800500 & first zero-isobase & 4 \\
Coquille 521 & 401900 & 4781000 & $\sim$ Maximum subsidence & 4 \\
Crescent City kc5 & 402000 & 4624000 & first zero-isobase & 5 \\
\hline
\end{tabular}

Notes: Data sources as follows: 1) Clague and Bobrowsky (1994a), 2) Peterson et al., (2013b), 3) this paper, 4) Peterson et al. (2012a), 5) Peterson et al. (2011). The trough of maximum subsidence in Oregon is likely located 10-30 east of the Siuslaw River 218b and Coquille 521, based on local trends of subsidence (Peterson et al., 2012a) and on comparisons with maximum subsidence site distances to the deformation front in southwestern Washington.

Three core logs in this compilation study that do not contain evidence of coseismic subsidence (Figure 13; Table 6) came from previous paleotsunami investigations including studies at Port Alberni (PA5/6/9), Vancouver Island, British Columbia (Clague \& Bobrowsky, 1994a), Discovery Bay, Washington (Williams et al., 2005) and Crescent City (CCkc5) in northernmost California (Peterson et al., 2011). Though 3-6 Cascadia paleotsunamis are recorded at the Port Alberni, Discovery Bay, and the Crescent City core sites, dating at least 1.3-2.5 ka, no tidal marsh subsidence events were observed in the continuous-peaty or rooted-mud core sections. One locality that we include without a core log is Tofino (TF4) on the west coast of Vancouver Island (Figure 5). The Tofino locality records only the last paleosubsidence event (0.5-1.0 m subsidence) from the AD 1700 Cascadia rupture (Clague \& Bobrowsky, 1994b; Guilbault, et al., 1995). Post-glacial rebound limits the age of tidal marsh development at the Tofino locality to less than $750 \mathrm{yr}$ BP.

\subsection{Extrapolation of Zero-Isobases in the North and South Areas of the Central Cascadia Margin}

Tidewater bodies diverge from the deformation front (80-200 km distance) from the south central margin to the northern central margin (Figure 5). Neither the north nor the south central margins individually provide constraints on both the first and second zero-isobases. However, by using the symmetry of oceanic plate widths, upper-plate lithology, and assumed megathrust coupling relations we extrapolate the first and second zero-isobases to the north and south of the central margin midpoint at about the position of the lower Columbia River mouth.

Coseismic subsidence core sites and associated subsidence conditions from Table 6 are shown in the regional map of the Cascadia margin (Figure 14). Sites TF, WA, GH, CR, SR, and CQ lie along the trough of maximum cosiesmic subsidence for ruptures recorded during the last $2.6 \mathrm{ka}$. The second zero-isobase for most ruptures is traced from PA in Vancouver Island to SC, MB and LV in Washington. The first zero-isobase for most ruptures is traced from $\mathrm{CC}$ in northern California to $\mathrm{CB}$ and $\mathrm{UR}$ in Oregon. These results differ substantially from coseismic subsidence interpretations by Leonard et al. (2010) and Witter et al. (2013), which assume that the maximum trough of subsidence occurs seaward of the coastline in south central Oregon, whereas the compilation shown here places the maximum trough of subsidence well landward of the coastline at SR and CQ.

Taking the second and first zero-isobases to be approximately equidistant from the trough of maximum coseismic subsidence we extrapolate the second zero-isobase along the length of Oregon and the first 
zero-isobase along the length of Washington and the southern part of Vancouver Island in British Columbia (Figure 14). The distance between the first zero-isobase and the deformation front reaches maximum values ( $\sim 100 \mathrm{~km}$ west-east distance) at the mid-point of the central margin, and diminishes to $60-80 \mathrm{~km}$ west-east distances at the northern and southern ends of the Juan de Fuca plate segment. The second zero-isobase reaches maximum west-east distances from the deformation front in the 1) Columbia River at LV (190 km distance), 2) Puget Sound at MB (220 km distance) and 3) Strait of Juan de Fuca at DB (230 km distance). The amounts of maximum coseismic subsidence, as recorded in across-margin traverses (Figures 7, 8, 9) reach a maximum of at least $1.5 \mathrm{~m}$ subsidence at $\mathrm{CR}$ and $\mathrm{GH}$ in south Washington and decreases to $0.5-1.0 \mathrm{~m}$ subsidence at WA in northernmost Washington and at TF on the west coast of Vancouver Island (Table 6, Figure 14).

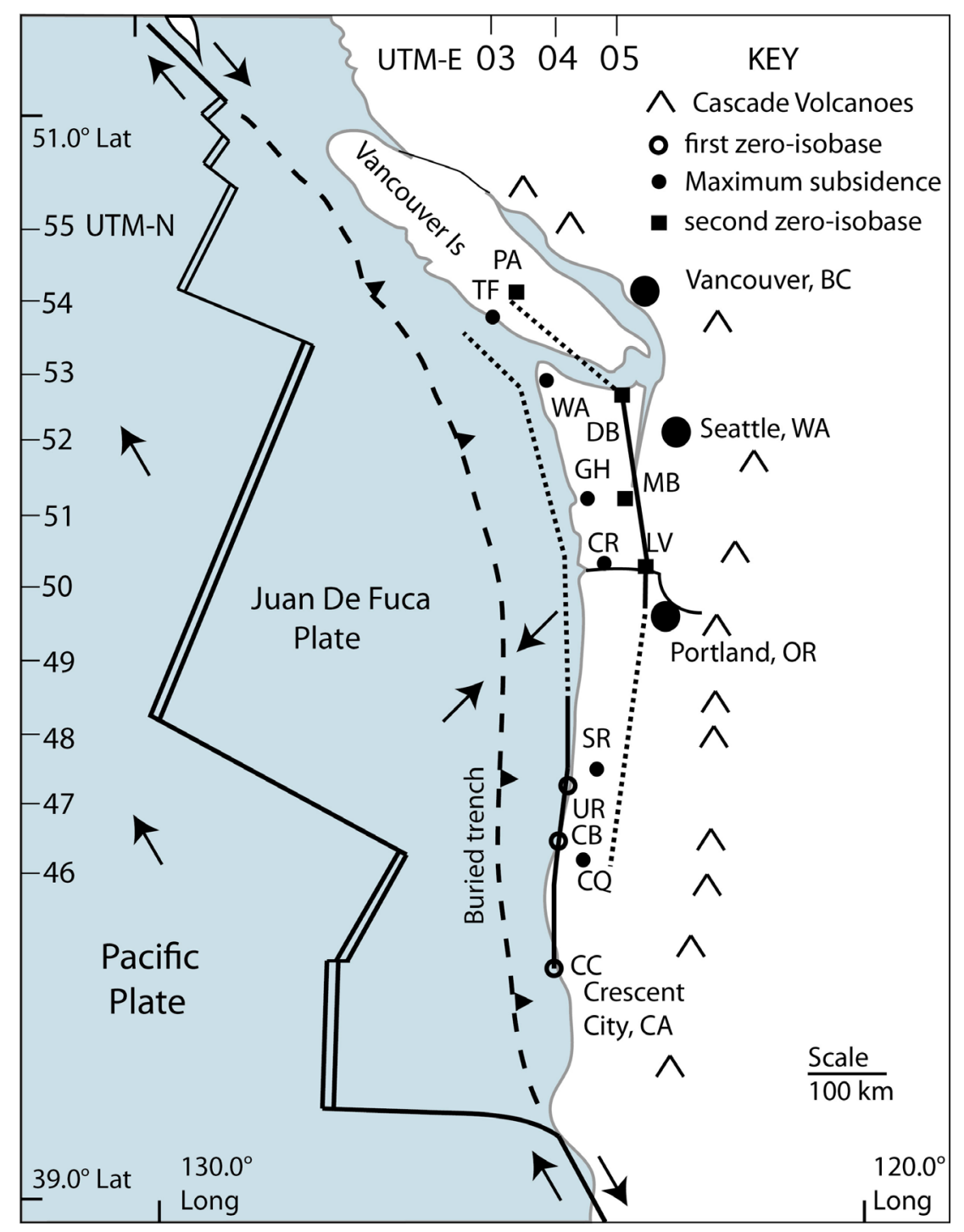

Figure 14. Map of estimated and extrapolated first and second zero-isobases

Map of first zero-isobase (open circle), trough of maximum coseismic subsidence (solid square), and second zero-isobase (solid circle) in the central Cascadia margin. Mapped positions and extrapolated trends (dotted lines) of the first and second zero-isobases are based on dated subsidence records (sites) and equidistant relations between the isobases and the trough of maximum subsidence. See Figure 13 for core site logs and Table 6 for core site position coordinates. The west-east distance between the deformation front and the first zero-isobase in central Oregon is estimated to be $\sim 100 \mathrm{~km}$. The west-east distances from the deformation front to second zero-isobase in southern Washington, at the Columbia River and at Grays Harbor, are 190 and $220 \mathrm{~km}$. Large metropolitan areas (large solid circles) are shown relative to first and second zero-isobases in the north central Cascadia margin. 


\subsection{Modern Horizontal Strain Accumulation Rates in the Upper-Plate}

Modern horizontal strain rates in the overriding North American plate are recorded in three west-east traverses of GPS station baselines that cross the Coast Ranges (Figure 10). Smaller strain rates are also recorded in northsouth baselines. The bidirectional horizontal strain components are consistent with oblique subduction of the Juan de Fuca oceanic plate under the North America plate. The baseline shortening strain rates in the west-east traverses are inhomogeneous (Table 4; Figure 10). The strain rates vary by factors of 3-4 between some adjacent baselines, such as NEAH-P403 $\left(-4.9 \times 10^{-8}\right)$ and P403-P435 $\left(-1.04 \times 10^{-7}\right)$ in the Neah traverse and HLSYSTHM $\left(-8.34 \times 10^{-8}\right)$ and STHM-P383 $\left(-2.08 \times 10^{-7}\right)$ in the Newport traverse. These differences in strain rates might indicate locally variable conditions of inter-plate coupling, possibly reflecting different upper-plate lithologies, inter-plate surface topology, and/or other coupling asperities at the viscoelastic megathrust interface. The unusually broad extent of upper-plate shortening or inter-plate coupling located in the Coast Ranges (Figure 15), is consistent with the apparent low rates of net tectonic uplift at 90-140 km east of the trench (Figure 12) and could account for modest long-term uplift of the Coast Ranges in southern Washington and northern Oregon since Miocene time. The origins of Coast Range uplift in southern Washington and northern Oregon are attributed to regional under-plating in the west coupled zones. Reported uplift ( $\sim 250 \mathrm{~m}$ tilting up to the east) of an early Plicocene formation, the Sandy River mudstone in the Portland basin (Trimble, 1963), is also coincident with the east coupled zone in the central GPS baseline (Seaside). It has yet to be established whether similar uplift occurs at the east coupled zones in the northern GPS baseline (Neah) and southern GPS baseline (Newport) (Figure 10).

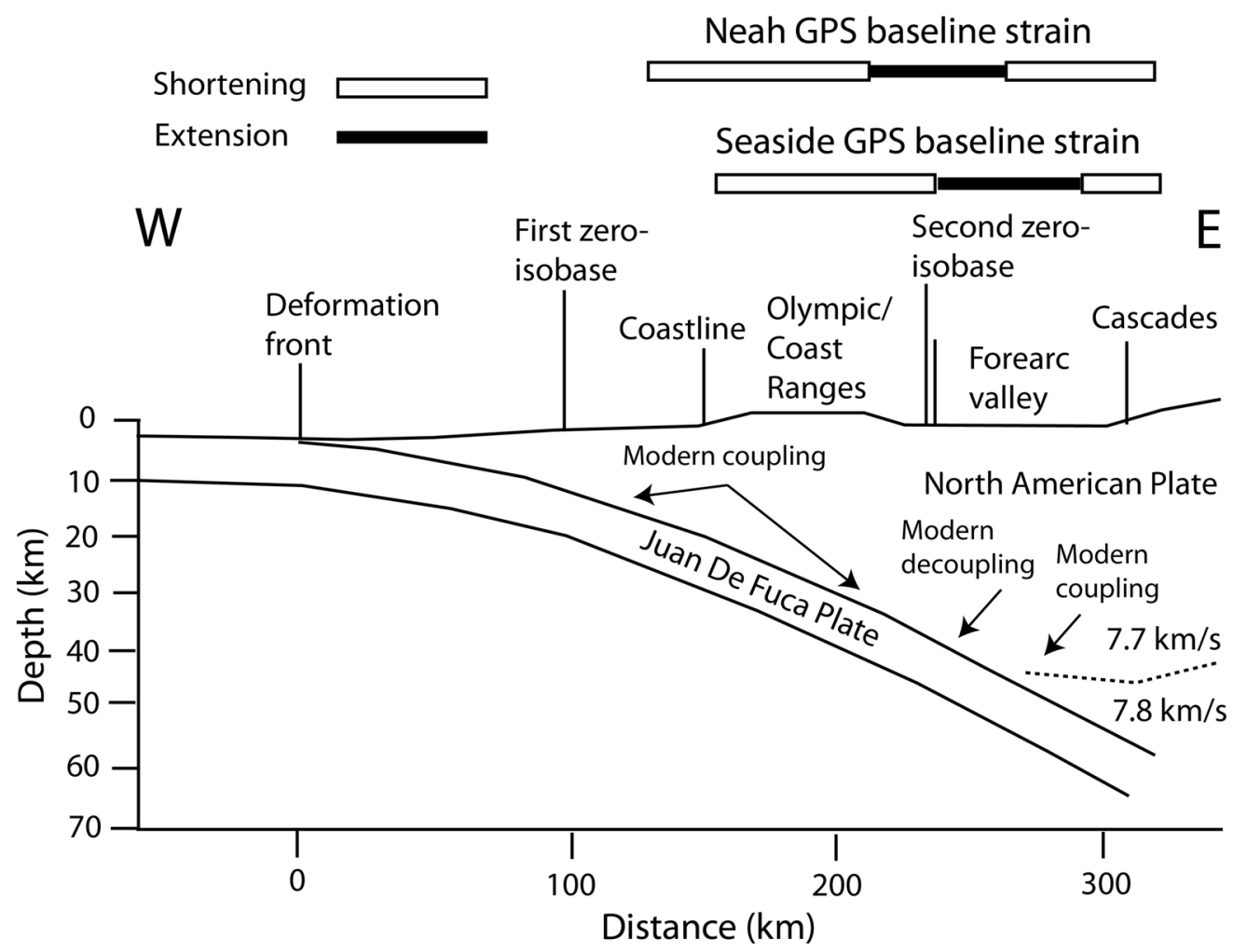

Figure 15. Diagram of geologic cross-section in the central Cascadia margin

Scaled geologic cross-section of the north central Cascadia margin, at the latitude of Willapa Bay (Figure 1). Upper-plate strain baseline traverses are from the Neah GPS traverse and the Seaside GPS traverse, located north and south, respectively, of the scaled geologic cross-section (Figure 10). Approximate locations of the first and second zero-isobases are taken from Figure 14. The base of the North American plate near the Cascade volcanic arc is taken at the seismic velocity change between 7.7 and $7.8 \mathrm{~km} \mathrm{~s}^{-1}$. The subduction geologic zone cross-section is redrafted from Parsons et al. (2005).

There are overall decreases in west-east strain rates with increasing distance landward from the coastlines in all three baseline traverses in northern Washington and central Oregon (Figure 10). The landward onset of extension 
in the Washington GPS traverse is observed at a distance of about $100 \mathrm{~km}$ from the coast, on the west side of the Puget forearc valley (Figure 11). The landward onset of extension in the Oregon GPS traverses is observed at $150 \mathrm{~km}$ distance from the coast, in the Willamette forearc valley. The west sides of the extension zones in all three GPS baseline traverses occur at about the same west-east distance $(\sim 200 \mathrm{~km})$ from the deformation front or the buried trench. The extension zones represent current conditions of inter-plate decoupling at the megathrust interface (Figure 15). The extension zones are coincident with the elongate forearc valleys and with episodic GPS station displacements, referred to as slow earthquakes (Gomberg et al., 2010).

Shortening strain zones are observed on the landward sides of the extension zones in all three of the GPS baseline traverses (Figure 10). These eastern shortening zones represent local coupling of the North American plate and the subducting Juan de Fuca plate. The eastern coupling zones apparently occur against buttresses of upper-plate thickening near the western flanks of the Casacade volcanic arc (Figures 10, 11, 15). The isolated west-east extension of the upper-plate in the vicinity of the forearc valleys requires some differential aseismic slip at the inter-plate interface. Work is underway to better constrain the mechanisms and distributions of the differential shear associated with the extension zones in the forearc valleys.

The shallow subduction of the Juan de Fuca plate $\left(12^{\circ}\right.$ at $200 \mathrm{~km}$ from the deformation front) (Figure 15) (Parsons et al., 2005) results in unusually-wide inter-plate coupled zones (Figure 16). The strongly coupled zone extends to the first zero-isobase and the transition zone extends to the second zero-isobase in the central Cascadia margin. The lower plate probably conforms to interseismic bending moments of the upper-plate within the landward reaches of both the strongly coupled zone and the transition zone. Such wide coupled zones could account for some apparent long ruptures (at least $500 \mathrm{~km}$ ) in the central Cascadia margin. Both upper and lower plates could release accumulated elastic strain during coseismic rupture of the wide coupled zone $(\sim 200 \mathrm{~km}$ in width), which nearly reaches the Portland, OR, and Seattle, WA, metropolitan areas in the central Cascadia margin (Figures 10 and 14).

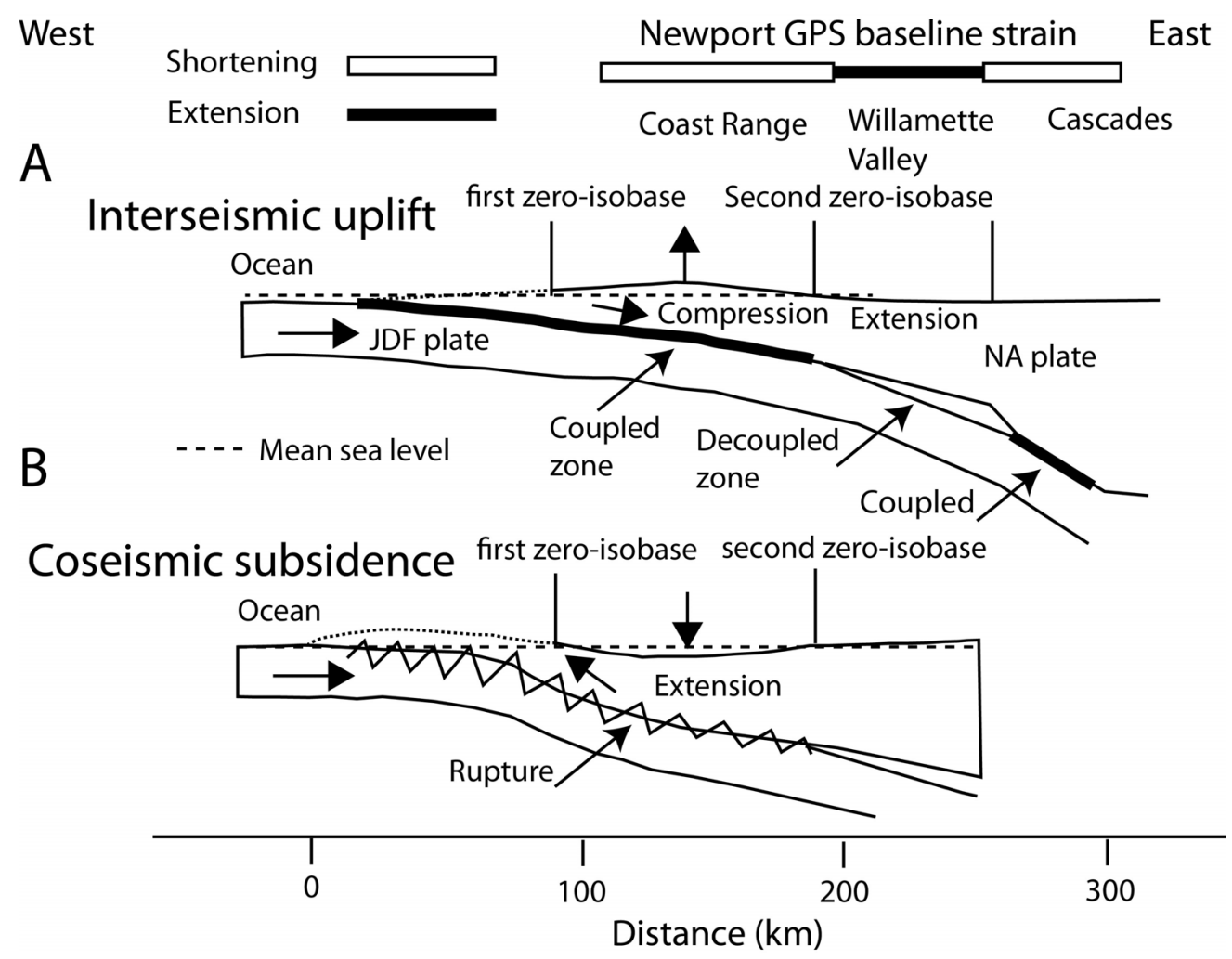

Figure 16. Diagrams of interseismic vertical displacement and inter-plate rupture

Interseismic vertical displacement (Part A) and inter-plate rupture (Pat B) are shown in a subduction zone profile from the south central Cascadia margin. The profile is horizontally-scaled (across-margin) to geographic features the latitude of the Newport GPS baseline. The first and second zero-isobase positions are from Figure 14. The unusually-wide rupture zone is taken from the landward extent of both the strongly coupled zone (Figure 2) and the transition zone, as based on upper-plate modern strain shortening (Figure 10). 


\section{Conclusions}

The central Cascadia margin is defined by a shallow-dipping megathrust between the oceanic Juan de Fuca plate segment and the continental North American plate. The central part of the Cascadia subducion zone is distinguished by 1) symmetrical tectonic features along the margin and 2) asymmetrical coastline and tidewater positions relative to the deformation front or buried trench. These relations provide the necessary neotectonic records to establish key widths of inter-plate coupling in the central area of the Cascadia subduction zone. A Quaternary fold and thrust belt or upper-plate deformation belt that is associated with strong inter-plate coupling is located offshore of the Washington coastline. The deformation belt or zone of strong inter-plate coupling intersects the south central Oregon coast where it is evident from high uplift rates and local uplift variability of late Pleistocene marine terraces.

Late Holocene records of elastic cyclic vertical displacement in the upper-plate are evident in tidal marshes along the Washington Pacific coast and in three tidal water bodies that extend well landward of the coastline in the north central margin. Coseismic subsidence is observed at the Columbia River, Grays Harbor, and Waatch tidal wetlands, thereby placing the entire Washington coast landward of the first-zero isobase. The amount of estimated coseismic paleosubsidence and the number of apparent subsidence events decrease with increasing distance landward from the trough of maximum coseismic subsidence to the second zero-isobase, located about 80-120 km from the Washington coast, for most rupture events during latest Holocene time.

Measurements of modern horizontal strain between GPS stations in the upper-plate are established in three across-margin baselines and one along-margin baseline in western Washington and western Oregon. Modern crustal shortening is occurring in both west-east and south-north orientations, reflecting inter-plate coupling from oblique subduction of the Juan de Fuca plate under the North American plate. West-east shortening across the central Cascadia margin is measured to distances of about $200 \mathrm{~km}$ from the deformation front.

Modern upper-plate shortening coincides with long-term uplift of the Coast Ranges and, at least locally, the western margin of the Cascade volcanic arc, due to regional under-plating at the megathrust interface (Figure 17). This is the first report of a mechanism that could account for the Coast Range uplift since Miocene time in Washington and Oregon. The intervening band of upper-plate lengthening or extension coincides with the Willamette forearc valley and the western Puget Sound forearc valley, which do not demonstrate long-term uplift. Little or no under-plating is expected to occur at the decoupled megathrust interface under the forearc valleys.

The modern GPS strain shortening to $\sim 200 \mathrm{~km}$ distance from the trench in three west-east baselines, used here as proxies for inter-plate coupling, contradict reported narrow coupled zones ( $\sim 100 \mathrm{~km}$ combined width) in the south-central Cascadia margin, as modeled from geothermal decoupling assumptions (Leonard et al., 2010; Witter et al., 2013). Much of the modern strain measured in the onshore GPS baselines is assumed to be elastic and it could contribute to seismic energy released during a future rupture of the widely-coupled megathrust. The substantial width of the combined coupled zone, reaching $200 \mathrm{~km}$ from the buried trench, as established from GPS baseline shortening (Figure 17), is consistent with a wide strongly-coupled zone, reaching $\sim 100 \mathrm{~km}$ distance landward from the buried trench in Oregon, based on marine terrace deformation. 


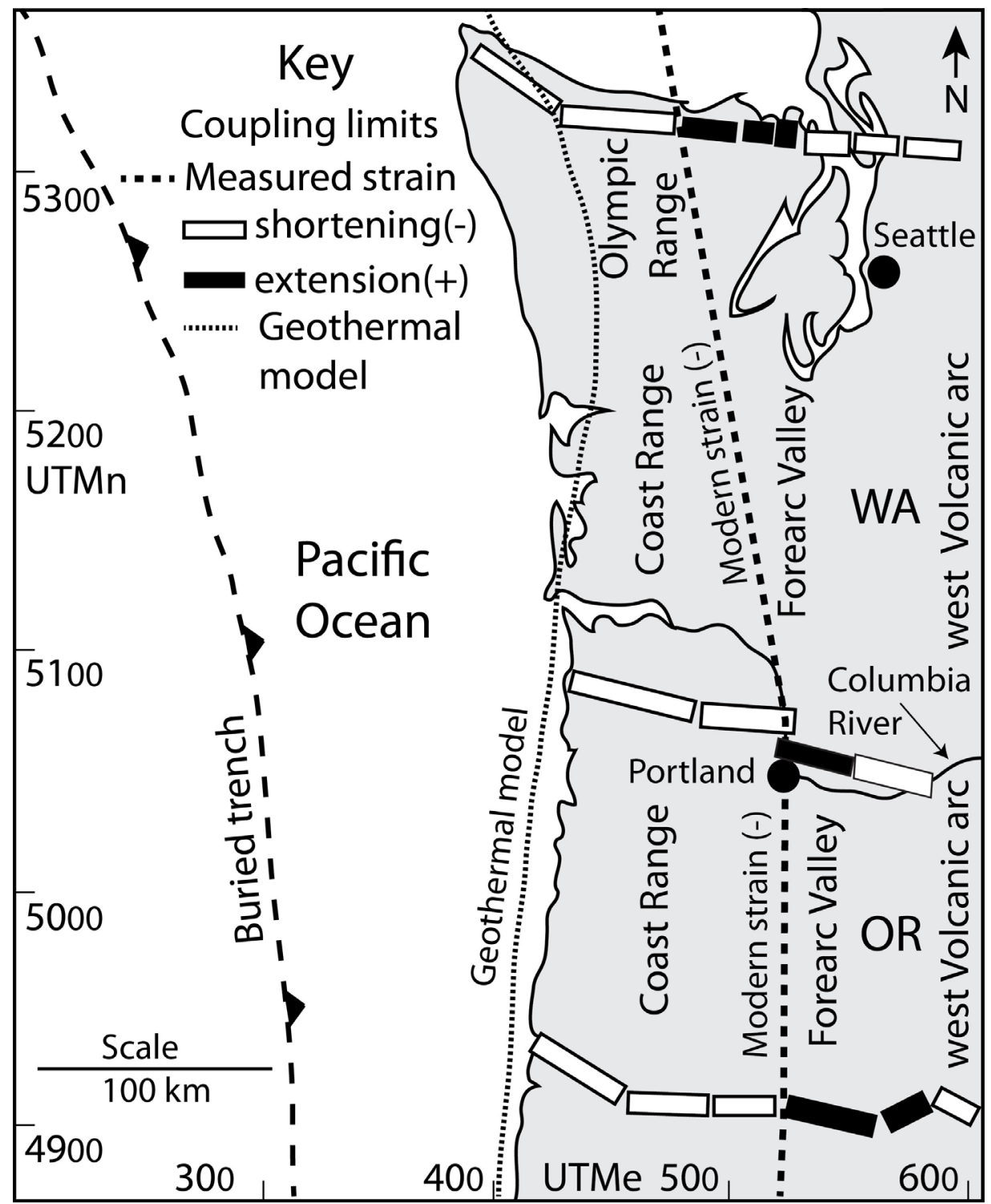

Figure 17. Landward limits of inter-plate coupling

Summary map of landward limits of inter-plate coupled zones estimated by geothermal modeling (thin dotted line) (Witter et al., 2013) and by modern GPS baseline shortening (bold dashed line) as presented in this article. The west coupled zone shown by modern strain shortenting in the upper-plate is about 100 percent wider or twice the width of the combined coupled zones predicted by geothermal modeling (Witter et al., 2013) in Oregon.

\section{Acknowledgements}

Chip Barnett performed core logging and diatom analysis of paleosubsidence events in Grays Harbor. Sandy Vanderburgh performed core logging of paleosubsidence events in the upper reaches of the Columbia River estuary. Dave Parks, Washington Department of Natural Resources, performed the GPS real time kinematic (RTK) surveys and post-processing in the Salt Creek tidal marsh. Mark Armstrong, National Geodetic Survey, NOAA, performed the GPS RTK surveys and post-processing in the Waatch Creek tidal wetlands. Sarah Sterling and John Dandridge assisted with core logging in the Pysht River marsh. Merrill \& Ring Inc. provided access to the Pysht River marsh. Ian Hutchinson provided cutbank core log data (SALTCB) from the Salt Creek marsh. Kurt Kristensen provided core logging assistance in the Dungeness Bay salt marsh. Dale Croes provided site and access information for the Mud Bay tidal marsh coring localities. Support for newly presented radiocarbon dating was provided by Portland State University. 


\section{References}

Adams, J. (1984). Active deformation of the Pacific Northwest continental margin. Tectonics, 3, 449-472. http://dx.doi.org/10.1029/TC003i004p00449

Adams, J. (1996). Great earthquakes recorded by turbidites off the Oregon-Washington coast. In M. Rogers, T. J. Walsh, W. J. Kockelman \& G. R. Priest (Eds.), USGS Professional Paper 1560 Assessing and Reducing Earthquake Hazards in the Pacific Northwest, 1, 147-160.

Atwater, B. F., \& Hemphill-Haley, E. (1997). Recurrence intervals for great earthquakes of the past 3,500 years at northeastern Willapa Bay, Washington. US Geological Survey Professional Paper 1576 (p. 108).

Atwater, B. F. (1987). Evidence for great Holocene earthquakes along the outer coast of Washington State (USA). Science, 236, 942-944. http://dx.doi.org/10.1126/science.236.4804.942

Atwater, B. F. (1992). Geologic evidence for earthquakes during the past 2000 years along the Copalis River, southern coastal Washington. Radiocarbon dates in Appendix as Supplement. Journal of Geophysical Research, 97, 1901-1919. http://dx.doi.org/10.1029/91JB02346

Atwater, B. F. (1997). Coastal evidence for great earthquakes in Western Washington. U.S. Geological Survey Professional Paper, 1560, 77-90.

Atwater, B. F., Nelson, A. R., Clague, J. L., Carver, G. A., Yamagouchi, D. K., Bobrowsky, P. T., ... Reinhart, M. A. (1995). Summary of coastal geologic evidence for past great earthquakes at the Cascadia Subduction Zone. Earthquake Sprectra, 11, 1-18. http://dx.doi.org/10.1193/1.1585800

Atwater, B. F., Tuttle, M. P., Schweig, E. S., Rubin, C. M., Yamaguchi, D. K., \& Hemphill-Haley, E. (2004). Earthquake recurrence, inferred from paleoseismology. In A. R. Gillespie, S. C. Porter \& B. F. Atwater (Eds.), The Quaternary Period in the United States (pp. 331-350), Elsevier, Amsterdam.

Barnett, E. T. (1997). Potential for coastal flooding due to coseismic subsidence in the central Cascadia margin. M.S. Thesis, Portland State University (p. 144).

Blais-Stevens, A., Rogers, G. C., \& Clague, J. J. (2011). A revised earthquake chronology for the last 4,000 years inferred from varve-bounded debris-flow deposits beneath an inlet near Victoria, British Columbia. Bulletin of the Seismological Society of America, 101, 1-12. http://dx.doi.org/10.1785/0120090360

Brandon, M. T., \& Calderwood, A. G. (1990). High pressure metamorphism and uplift of the Olympic $\begin{array}{llll}\text { subduction } \quad \text { Geology, } & 18, & 1252-1255 \text {. }\end{array}$ http://dx.doi.org/10.1130/0091-7613(1990)018<1252:HPMAUO>2.3.CO;2

Briggs, G. G. (1994). Coastal crossing of the elastic strain zero-isobase, Cascadia margin, south-central Oregon coast. M.S. Thesis, Portland State University, Portland, Oregon (p. 251).

Bucknam, R. C., Hemphill-Haley, E., \& Leopold, E. B. (1992). Abrupt uplift within the past 1700 years at southern Puget Sound, Washington. Science, 1611-1614. http://dx.doi.org/10.1126/science.258.5088.1611

Chappell, J. E. B., \& Shackleton, N. J. (1986). Oxygen isotopes and sea level. Nature, 324, $137-140$. http://dx.doi.org/10.1038/324137a0

Clague, J. J., \& Bobrowsky, P. T. (1994a). Tsunami deposits beneath tidal marshes on Vancouver Island, British Columbia. Geological Society of America Bulletin, 106, 1293-1303. http://dx.doi.org/10.1130/0016-7606(1994)106<1293:TDBTMO>2.3.CO;2

Clague, J. J., \& Bobrowsky, P. T. (1994b). Evidence for a large earthquake and tsunami 100-400 years ago on the western Vancouver Island, British Columbia. Quaternary Research, 41, 176-184. http://dx.doi.org/10.1006/qres.1994.1019

Clifton, H. E. (1994). Transgressive and early highstand systems tracts: Pleistocene terrace deposits Willapa Bay, Washington. Paper presented at the Field Trip Guide, Society of Economic Petrology and Mineralogy, Research Conference: Clastic Deposits of the Transgressive Systems Tract, Long Beach, Washington.

Crosson, R. S., \& Owens, T. J. (1987). Slab geometry of the Cascadia subduction zone beneath Washington from earthquake hypocenters and teleseismic converted waves. Geophysical Research Letters, 14, 824-827. http://dx.doi.org/10.1029/GL014i008p00824

Cruikshank, K. M., \& Peterson, C. D. (2013). Strain Energy Release from the 20119.0 Mw Tōhoku Earthquake, Japan. Open Journal of Earthquake Research, 2, 75-83. http://dx.doi.org/10.4236/ojer.2013.24008 
Darienzo, M. E., \& Peterson, C. D. (1990). Episodic tectonic subsidence of late-Holocene salt marsh sequences in Netarts Bay, Oregon, Central Cascadia Margin, USA. Tectonics, 9, 1-22. http://dx.doi.org/10.1029/TC009i001p00001

Darienzo, M. E., \& Peterson, C. D. (1995). Magnitude and frequency of subduction-zone earthquakes along the northern Oregon coast in the past 3,000 years. Oregon Geology, 57, 3-12.

Dragovich, J. D., Logan, R. L., Schasse, H. W., Walsh, T. J., Lingley, W. S., Norman, D. K., ... Meyers, K. D. (2002). Geologic Map of Washington-Northwest Quadrant.

Fisher, M. A., Hyndman, R. D., Johnson, S. Y., Brocher, T. M., Crosson, R. S., Wells, R. E., ... ten Brink, U.S. (2005). Crustal structure and earthquake hazards of the subduction zone in southwest British Columbia and western Washington In C. R. Kayen (Ed.), US Geological Survey, Professional Paper 1661 (p. 23). Retrieved March 1, 2013, from http://pubs.usgs.gov/pp/pp1661c/pp1661c.pdf

Flemming, K., Johnston, P., Zwatz, D., Yokoyama, Y., Lambeck, K., \& Chappell, J. (1998) Refining the eustatic sea-level curve since the last glacial maximum using far- and intermediate-field sites. Earth and Planetary Science Letters, 163, 327-342. http://dx.doi.org/10.1016/S0012-821X(98)00198-8

Geist, E. L. (2005) Local tsunami hazards in the Pacific Northwest from Cascadia subduction zone earthquakes. In R. Kayen (Ed.), US Geological Survey, Professional Paper1661-B, (p. 12). Retrieved May 9, 2006, from http://pubs.usgs.gov/pp/pp1661c/pp1661c.pdf

Goldfinger, C., Grijalva, K., Bürgmann, R., Morey, A. E., Johnson, J. E., Nelson, H., ... Gràcia, E. (2008). Late Holocene rupture of the northern San Andreas Fault and possible stress linkage to the Cascadia Subduction Zone. Bulletin of the Seismological Society of America, 98, 861-889. http://dx.doi.org/10.1785/0120060411

Goldfinger, C., Kulm, L. D., Yeats, R. S., McNeil, L., \& Hummon, C. (1997). Oblique strike-slip faulting of the central Cascadia submarine forearc. Journal of Geophysical Research, 102, 8217-8243. http://dx.doi.org/10.1029/96JB02655

Goldfinger, C., Kulm, L. D., Yeates, R. S., Appelgate, B., MacKay M. E., \& Moore, G. F. (1992a) Transverse structural trends along the Oregon convergent margin: Implications for Cascadia earthquake potential and crustal rotations. Geology, 20, 141-144. http://dx.doi.org/10.1130/0091-7613(1992)020<0141:TSTATO >2.3.CO;2

Goldfinger, C., Kulm, L. D., Yeats, R. S., Mitchell, C., Weldon, R., Peterson, C., ... Priest., G. R. (1992b). Neotectonic map of the Oregon continental margin and adjacent abyssal plain. Open-File Report 0-92-4, Oregon Department of Geology and Mineral Resources, Portland, Oregon, $17 \mathrm{p}$ and maps.

Gomberg, J., Cascadia 2007 and Beyond Working Group (2010). Slow-slip phenomena in Cascadia from 2007 and beyond: A review. Geological Society of America Bulletin, 122, 963-978. http://dx.doi.org/10.1130/B30287.1

Guilbault, J. P., Clague J. J., \& Lapointe, M. (1995). Amount of subsidence during a late Holocene earthquake - evidence from fossil tidal marsh foraminfera at Vancouver Island, west coast of Canada. $\begin{array}{lllll}\text { Paleogeography, } \quad \text { Paleoclimatology, } & \text { Paleoecology, } & 118, & \text { 49-71. }\end{array}$ http://dx.doi.org/10.1016/0031-0182(94)00135-U

Hemphill-Haley, E. (1995). Intertidal diatoms from Willapa Bay, Washington: Application to studies of small-scale sea-level changes. Northwest Science, 69, 29-45.

Heusser, C. J. (1977). Quaternary palynology of the Pacific Slope of Washington. Quaternary Research, 8 , 282-306. http://dx.doi.org/10.1016/0033-5894(77)90073-4

http://www.cbs.state.or.us/external/bcd/programs/structural/Seismic_Codes-Oregon_History_020712.pdf. Last accessed September, 13, 2013.

Hutchinson, I., Peterson, C. D., \& Sterling, S. (2013). Late Holocene tsunami deposits at Salt Creek, Washington, USA. Science of Tsunami Hazards, 32(4), 221-235.

Hyndman, R. D., \& Wang, K. (1995). The rupture zone of the Cascadia great earthquakes from current deformation and thermal regime. Journal of Geophysical Research, 100, 22133-22154. http://dx.doi.org/10.1029/95JB01970

Hyndman, R. D., Yorath, C. J. Clowes, R. M., \& Davis, E. E. (1990). The northern Cascadia subduction zone at Vancouver Island, seismic structure and tectonic history. Canadian Journal of Earth Sciences, 27, 313-329. http://dx.doi.org/10.1139/e90-030 
Jurney, C. (2001) Refining the measured frequency of great earthquakes along the Cascadia subduction zone. M.S. thesis, Central Washington University, Ellensberg.

Leonard, L. J., Currie, C. A., Mazzotti, S., \& Hyndman, R. D. (2010). Rupture area and displacement of past Cascadia great earthquakes from coastal coseismic subsidence. Geological Society of America Bulletin, 122, 2079-2096. http://dx.doi.org/10.1130/B30108.1

McCaffery, R., \& Goldfinger, C. (1995). Forearc deformation and great subduction earthquakes: Implications for $\begin{array}{lllll}\text { Cascadia offshore } & \text { earthquake }\end{array}$ http://dx.doi.org/10.1126/science.267.5199.856

McCaffrey, R., Qamar, A. I., King, R. W., Wells, R., Khazaradze, G., Williams, C. A., ... Zwick, P. C. (2007). Fault locking, block rotation and crustal deformation in the Pacific Northwest. Geophysical Journal International, 169, 1315-1340. http://dx.doi.org/10.1111/j.1365-246X.2007.03371.x

McCory, P. A., Foster, D. S., Danforth W. W., \& Hamer, M. R. (2005). Crustal deformation at the leading edge of the Oregon coast range block, offshore Washington (Columbia River to Hoh River), in R. Kayen (Ed.), US Geological Survey, Professional Paper1661-A (p. 47). Retrieved May 9, 2006, from http://pubs.usgs.gov/pp/pp1661c/pp1661c.pdf

McNeil, L. C., Goldfinger, C., Yeates, R. S., \& Kulm, L. D. (1998). The effects of upper plate deformation on records of prehistoric Cascadia subduction zone earthquakes. In I. S. Stewart \& C. Vita-Finzi (Eds.), Coastal Tectonics. Geological Society of London, 146, 321-342,

Mosher, D. C., \& Hewitt, A. T. (2004). Late Quaternary deglaciation and sea-level history of eastern Juan de Fuca Strait, Cascadia. Quaternary International, 121, 23-39. http://dx.doi.org/10.1016/j.quaint.2004.01.021

Mulder, R. A., (1992) Regional tectonic deformation of the northern Oregon coast as recorded by Pleistocene marine terraces, M.S. Thesis, Portland State University, Portland, Oregon (p. 96).

Niem, A. R., \& Niem, W. A. (Cartographer) (1985), Oil and Gas investigations of the Astoria Basin, Clatsop and northernmost Tillamook Counties, northwest Oregon. Oregon Department of Geology and Mineral Industries [OGI-14], Portland, Oregon. Maps.

NOAA, (2013), NOAA CORS. Retrieved March 15, 2013, from http:/geodesy.noaa.gov/CORS/

OBCD. (2012). Earthquake design history 2012: A summary of requirements in the State of Oregon. Oregon Building Codes Division, Salem, Oregon.

Ovenshine, A. T., Lawson, D. E., \& Bartsch-Winkler, S. R. (1976). The Placer River silt-an intertidal deposit caused by the 1964 Alaska Earthquake. Journal Research, U S Geological Survey, 4, 151-162.

Parsons, T., Blakely, R. J., Brocher, T. M., Christensen, N. I., Fisher, M. A., Flueh, E., ... Wells, R. E. (2005). Crustal structure of the Cascadia fore arc of Washington, in R. Kayen (Ed.), US Geological Survey, Professional Paper1661-D, p. 36. Retrieved May 9, 2006, from http://pubs.usgs.gov/pp/pp1661c/pp1661c.pdf

Pazzaglia, F. J., \& Brandon, M.T. (2001) A fluvial record of long-term steady state uplift and erosion across the Cascadia forearc high, western Washington State. American Journal of Science, 301, 385-431. http://dx.doi.org/10.2475/ajs.301.4-5.385

Peterson C. D., Cruikshank, K. M., Darienzo, M. E., Wessen, G., Butler, V. \& Sterling, S. (2013b). Coseismic subsidence and paleotsunami run-up records from latest Holocene deposits in the Waatch Valley, Neah Bay, northwest Washington, USA: Links to great earthquakes in the northern Cascadia margin. Journal of Coast Research, 29, 157-172. http://dx.doi.org/10.2112/JCOASTRES-D-12-00031.1

Peterson C., Carver, C., Cruikshank, K., Abramson, H., Garrison-Laney, C., \& Dengler, L. (2011). Evaluation of the use of paleotsunami deposits to reconstruct inundation distance and run-up heights associated with prehistoric inundation events, Crescent City, southern Cascadia margin. Earth Surface Processes and Landforms, 36(7), 967-980. http://dx.doi.org/10.1002/esp.2126

Peterson, C. D., Barnett, E., Briggs, G., Carver, C., Clague, J., \& Darienzo, M. (1997). Estimates of coastal subsidence from great earthquakes in the Cascadia subduction zone, Vancouver Island B.C., Washington, Oregon, and Northernmost California. Oregon Geology and Mineral Industries, Open-File Report 0-07-5, p. 44. 
Peterson, C. D., Clague, J. J Carver, G. A., \& Cruikshank K. M. (2013a). Recurrence intervals of major paleotsunamis as calibrated by historic tsunami deposits in three localities: Port Alberni, Cannon Beach, and Crescent City, along the Cascadia margin, Canada and the USA. Natural Hazards.

Peterson, C. D., Cruikshank, K. M., Schlichting, R. B., \& Braunsten, S. (2010a). Distal Runup Records Of Latest Holocene Paleotsunami Inundation In Alluvial Flood Plains: Neskowin and Beaver Creek, Oregon, Central Cascadia Margin, USA. Journal of Coastal Research, 26, 622-634. http://dx.doi.org/10.2112/08-1147.1

Peterson, C. D., Darienzo, M. E., Hamilton, D., Pettit, D. J., Yeager, R. K., Jackson, P. L., ... Terich, T. A. (1994). Cascadia Beach-Shoreline Data Base, Pacific Northwest Region, USA. Oregon Department of Geology and Mineral Industries Open-File Report 0-94-2, p. 29, and 3 Electronic Database Files, Portland, Oregon.

Peterson, C. D., Grathoff, G. H., Reckendorf, F., Percy, D., \& Price, D. M., (2014). Late Pleistocene coastal loess deposits of the central west coast of North America: Terrestrial facies indicators for marine low-stand intervals. Aeolian Research, 12, 47-64. http://dx.doi.org/10.1016/j.aeolia.2013.11.001

Peterson, C. D., Vanderburgh, S., Roberts, M. C., Jol, H. M., Phipps, J. P., \& Twichell, D. C. (2010b). Composition, age, and depositional rates of Holocene shoreface deposits under barriers and beach plains of the Columbia River littoral cell, USA. Marine Geology, 273, 62-82. http://dx.doi.org/10.1016/j.margeo.2010.02.004

Peterson, C. P., \& Gray, J. J. (Cartographer) (1986). Geologic map of the ocean floor off Oregon and the adjacent continental margin [GMS-42]. Oregon Department of Geology and Mineral Industries, Portland, Oregon.

Peterson, C. D., \& Darienzo, M. E. (1996). Discrimination of flood, storm and tectonic subsidence events in coastal marsh records of Alsea Bay, Central Cascadia Margin, USA. In A. M. Rogers, T. J. Walsh, W. J. Kockelman \& G. R. Priest (Eds.), USGS Professional Paper 1560 Assessing and Reducing Earthquake Hazards in the Pacific Northwest, 1, 115-146.

Peterson, C. D., Cruikshank, K. M., \& Darienzo. M. E. (2012a). Coastal tectonic strain and paleoseismicity in the south central Cascadia margin, Oregon, USA. In K. Konstantinou (Ed.), Natural Disaster Research, Prediction and Mitigation: Earthquakes: Triggers, Environmental Impact and Potential Hazards. NOVA Open Access Publisher, New York. pp 1-37. https://www.novapublishers.com

Peterson, C. D., Doyle, D. L., \& Barnett, E. T. (2000). Coastal flooding and beach retreat from coseismic subsidence in the central Cascadia margin, USA. Environmental and Engineering Geology, 6, 255-269.

Peterson, C. D., Minor, R., Gates, E. B., Vanderburgh, S., \& Carlisle, K. (2012b). Correlation of Tephra Marker Beds In Latest Pleistocene and Holocene Fill Of The Submerged Lower Columbia River Valley, Washington and Oregon, U.S.A. Journal of Coastal Research, 28, 1362-1380. http://dx.doi.org/10.2112/JCOASTRES-D-11-00181.1

Plafker, G., (1972). Alaskan earthquake of 1964 and Chilean earthquake of 1960. Implications for arc tectonics. Journal of Geophysical Research, 77, 901-925. http://dx.doi.org/10.1029/JB077i005p00901

PNGA. (2013). Pacific Northwest Geodetic Array, Central Washington University. Retrieved March 15, 2013, from http://www.geodesy.cwu.edu/

R Core Team (2012) R: A Language and Environment for Statistical Computing. R Foundation for Statistical Computing,Vienna, Austria. Retrieved December 1, 2012, from http://www.R-project.org

Rau, W. W. (1973) Geology of the Washington coast, between Point Grenville and the Hoh River, Washington Department of Natural Resources Bulletin no 66, p. 58. Olympia, Washington.

Rau, W. W. (1979) Geologic map in the vicinity of the lower Bogachiel and Hoh River valleys, and the Washington Coast: Washington Division of Geology and Earth Resources Geologic map GM-24, scale 1:62,500, Olympia, Washington.

Saffer, D. M. \& Bekins, B. A. (2006). An evaluation of factors influencing pore pressure in accretionary complexes: Implications for taper angle and wedge mechanics, Journal of Geophysical Research, 111, B04101. http://dx.doi.org/10.1029/2005JB00399

Satake, K., Shimazaki, K., Tsuji, Y., \& Ueda, K. (1996). Time and size of giant earthquake in Cascadia inferred from Japanese tsunami records of January 1700. Nature, 378, 246-249. http://dx.doi.org/10.1038/379246a0 
Shennan, I., Long, A. Rutherford, M. Green, F. Innes, J. Loyd, J. Zong, Y. \& Walker, K. (1996) Tidal marsh stratigraphy, sea-level change and large earthquakes., 5000 year record of large earthquakes in Washington, USA. Quaternary Science Reviews, 15, 1023-1059. http://dx.doi.org/10.1016/S0277-3791(96)00007-8

Smith, D. G., Meyers, R. A., \& Jol, H. M. (1999). Sedimentology of an upper-mesotidal (3.7 m) Holocene barrier, Willapa Bay, SW Washington, USA. Journal of Sedimentary Research, 69, 1290-129. http://dx.doi.org/10.2110/jsr.69.1290

Snavely, P. D. Jr., \& Wells, R. E. (1996). Cenozoic evolution of the continental margin of Oregon and Washington. In A. M. Rogers, T. J. Walsh, W. J. Kokelman \& G. R. Priest, Assessing Earthquake Hazards and Reducing Risk in the Pacific Northwest, U.S. Geological Survey Professional Paper 1560 (pp. 161-182). Reston, Virginia.

Specmap. (2013). Global Change Master Directory. Retrieved March 15, 2013, from http://gcmd.nasa.gov/records/GCMD_EARTH_LAND_NGDC_PALEOCL_SPECMAP.html

Stuiver, M., Reimer, P. J., \& Reimer, R. W. (2012). CALIB v6.0 Radiocarbon calibration, Version 6.0. Retrieved September 25, 2012, from http://calib.qub.ac.uk/calib/[WWW program and documentation]

Thackray, G. D. (1998). Convergent-margin deformation of Pleistocene strata on the Olympic coast of Washington, USA. In I.S. Stewart \& Vita-Finzi (Eds.), Coastal Tectonics. Geological Society, London, Special Publications, 146, 199-211. http://dx.doi.org/10.1144/GSL.SP.1999.146.01.11

Thackray, G. D. (2001). Extensive Early and Middle Wisconsin glaciation on the Western Olympic Peninsula, Washington, and the variability of Pacific moisture delivery to the Northwestern United States, Quaternary Research, 55, 257-270. http://dx.doi.org/10.1006/qres.2001.2220

Tolman, B., Harris, R. B., Gaussiran, T., Munton, D., Little, J., Mach, R., ... Schlossberg D. (2004). The GPS Toolkit -- Open Source GPS Software, Proceedings of the 17th International Technical Meeting of the Satellite Division of the Institute of Navigation (ION GNSS 2004), Long Beach, California.

Trimble, D. E. (1963). Geology of Portland, Oregon and adjacent areas. U.S. Geological Survey Bulletin 1119 (p. 119).

Vanderburgh, S., Roberts, M. C., Peterson, C. D., Phipps, J. B. \& Herb, A. (2010) Holocene transgressive and regressive deposits of the Columbia River littoral cell barriers and beach plains. Marine Geology, 273, 32-43, 2010. http://dx.doi.org/10.1016/j.margeo.2010.02.002

Washington Division of Geology and Earth Resources. Geologic Map GM-50 1:250,000 scale.

Wells, R. E. (1990) Paleomagnetic roations and the Cenozoic tectonics of the Cascade arc, Washington, Oregon, and California. Journal of Geophysical Research, 95(B12), 19409-19417. http://dx.doi.org/10.1029/JB095iB12p19409

Wells, R. E., Engebertson, D. C., Snavely, P. D. Jr., \& Coe, R. S. (1984). Cenozoic plate motions and the volcan-tectonic evolution of western Oregon and Washington. Tectonics, 3, 275-294. http://dx.doi.org/10.1029/TC003i002p00275

West, D. O., \& McCrumb, D. R. (1999). Coastline uplift in Oregon and Washington and the nature of Casadia $\begin{array}{lllll}\text { subduction } \quad \text { zone } & \text { Geology, } & 16, & 169-172 .\end{array}$ http://dx.doi.org/10.1130/0091-7613(1988)016<0169:CUIOAW $>2.3 . C O ; 2$

Williams, H. F. L., Hutchinson, I., \& Nelson, A. R. (2005). Multiple sources for late-Holocene tsunamis at Discovery Bay, Washington Sate, USA. The Holocene, 15, 60-73. http://dx.doi.org/10.1191/0956683605hl784rp

Witter, R. C., Zhang Y. J., Wang K., Priest G. R., Goldfinger, C., Stimely L., ... Ferro, P. A. (2013) Simulated tsunami inundation for a range of Cascadia megathrust earthquake scenarios at Bandon, Oregon, USA. Geosphere, 9, 1783-1803. http://dx.doi.org/10.1130/GES00899.1

\section{Copyrights}

Copyright for this article is retained by the author(s), with first publication rights granted to the journal.

This is an open-access article distributed under the terms and conditions of the Creative Commons Attribution license (http://creativecommons.org/licenses/by/3.0/). 